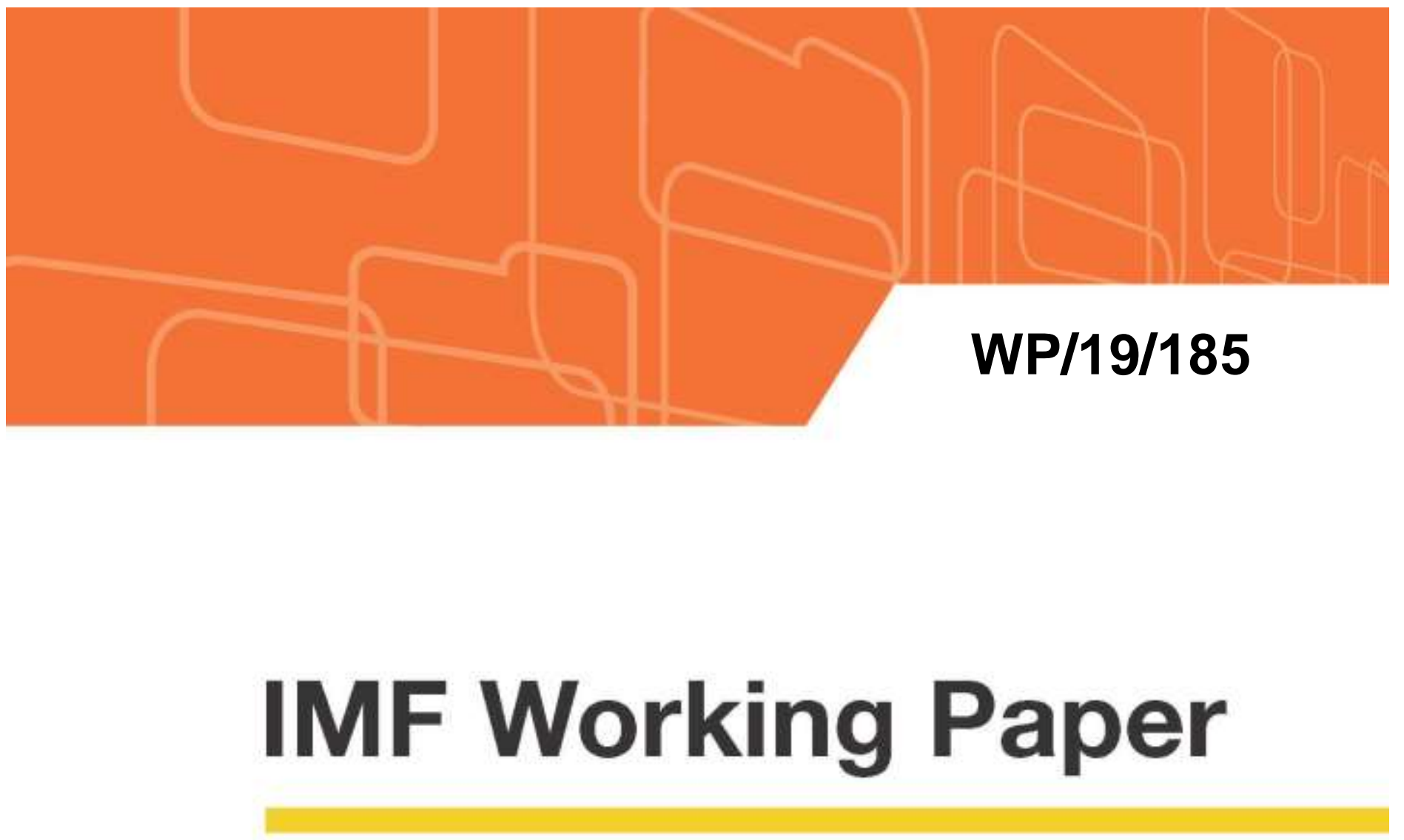

\title{
Macroeconomic and Financial Policies for Climate Change Mitigation: A Review of the Literature
}

by Signe Krogstrup and William Oman

IMF Working Papers describe research in progress by the author(s) and are published to elicit comments and to encourage debate. The views expressed in IMF Working Papers are those of the author(s) and do not necessarily represent the views of the IMF, its Executive Board, or IMF management. 


\title{
IMF Working Paper
}

Monetary and Capital Markets Department

Research Department

\section{Macroeconomic and Financial Policies for Climate Change Mitigation: A Review of the Literature}

\section{Prepared by Signe Krogstrup and William Oman ${ }^{1}$}

Authorized for distribution by Ulric Eriksson von Allmen and Oya Celasun

September 2019

\section{IMF Working Papers describe research in progress by the author(s) and are published to elicit comments and to encourage debate. The views expressed in IMF Working Papers are those of the author(s) and do not necessarily represent the views of the IMF, its Executive Board, or IMF management.}

\begin{abstract}
Climate change is one of the greatest challenges of this century. Mitigation requires a largescale transition to a low-carbon economy. This paper provides an overview of the rapidly growing literature on the role of macroeconomic and financial policy tools in enabling this transition. The literature provides a menu of policy tools for mitigation. A key conclusion is that fiscal tools are first in line and central, but can and may need to be complemented by financial and monetary policy instruments. Some tools and policies raise unanswered questions about policy tool assignment and mandates, which we describe. The literature is

\footnotetext{
${ }^{1}$ This paper benefited from comments from Ruchir Agarwal, Michel Aglietta, Alexander Barkawi, Nicoletta Batini, Peter Birch Sørensen, Per Callesen, Oya Celasun, Martin Čihák, Giovanni Dell’Ariccia, Ulric Eriksson von Allmen, Etienne Espagne, Mai Farid, Pierpaolo Grippa, Dirk Heine, Martin Holmberg, Florence Jaumotte, Prakash Loungani, Donald Marron, Leonardo Martinez-Diaz, Paolo Mauro, Irene Monasterolo, Pierre Monnin, Rasmus Pank, Ian Parry, Catherine Pattillo, Antonin Pottier, James Roaf, Frédéric Samama, Romain Svartzman, and Johannes Wiegand. The views expressed in this paper are those of the authors and should not be attributed to Danmarks Nationalbank, the IMF, its Executive Board, or its management.
} 
scarce, however, on the most effective policy mix and the role of mitigation tools and goals in the overall policy framework.

JEL Classification Numbers: Q54, E52, E60, E61, E62, G10, G20

Keywords: climate change, fiscal policy, monetary policy, financial policy, policy framework, policy coordination

Author's E-Mail Address: skro@nationalbanken.dk, woman@imf.org 


\section{CONTENTS}

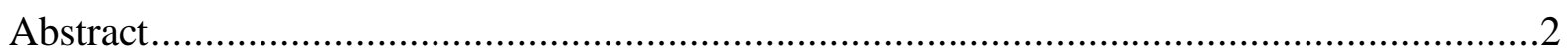

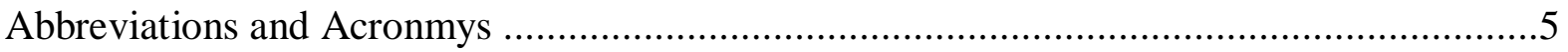

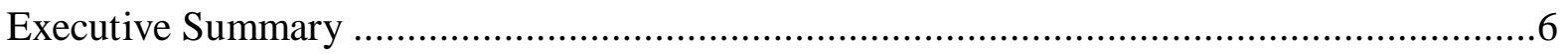

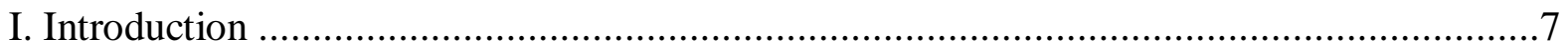

II. Setting the Stage: The Case for Policy Action ........................................................

A. Climate Science and the Cost of Climate Change ..................................................9

B. What Needs to Be Achieved? ........................................................................... 11

C. Why Is Mitigation Not Taking Place via the Market? ............................................. 14

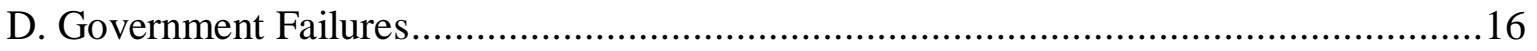

III. Macroeconomic and Financial Policies for Climate Change Mitigation.........................17

A. Fiscal Policy Tools ...................................................................................... 19

B. Financial Policy Tools............................................................................................22

Redressing the mispricing and increasing the transparency of climate risks...............23

Reducing short-term bias, improving governance frameworks of financial institutions. 26

Supporting the development of markets for green financial securities .......................27

Actively promoting climate finance using financial regulatory tools ..........................28

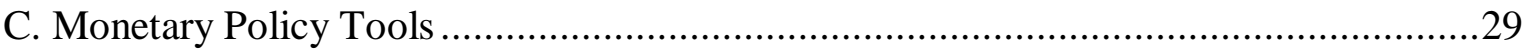

D. Other Policies for Climate Change Mitigation ................................................ 33

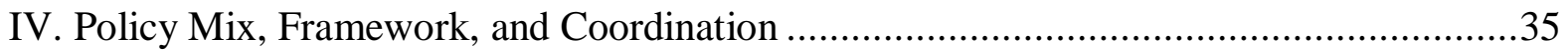

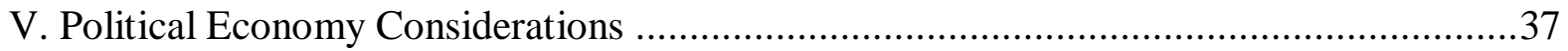

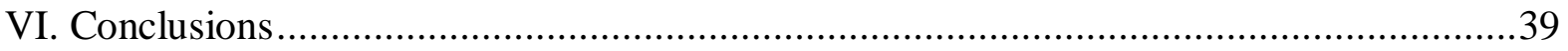

Appendix: Integrated Assessment Models ........................................................41

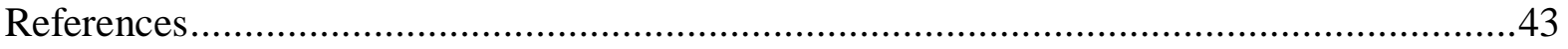




\section{AbBreviations AND ACRONMYS}

\begin{tabular}{ll} 
BCBS & Basel Committee on Banking Supervision \\
DNB & De Nederlandsche Bank \\
ECB & European Central Bank \\
ESG & Environmental, Social and Governance \\
ESRB & European Systemic Risk Board \\
EU & European Union \\
GHGs & Greeenhouse gases \\
IAMs & Integrated Assessment Models \\
IPCC & Intergovernmental Panel on Climate Change \\
NDCs & Nationally Determined Contributions \\
NGFS & Network of Central Banks and Supervisors for Greening the Financial System \\
PBoC & People's Bank of China \\
PPF & Production possibility frontier \\
R\&D & Research and development \\
TCFD & Task Force on Climate-related Financial Disclosures \\
SDGs & United Nations Sustainable Development Goals \\
SVMA & Social Value of Mitigation Action \\
UNEP & United Nations Environment Programme \\
UNFCCC & United Nations Framework Convention on Climate Change \\
\hline
\end{tabular}




\section{EXECUTIVE SUMMARY}

\section{Mitigating climate change requires a large-scale transition to a low-carbon economy.} The scientific consensus is that climate change is undermining the ecological systems on which human and all other forms of life depend, and that mitigating climate change is crucial to preserving the conditions for economic growth and life within earth systems. There is also a strong scientific consensus that limiting global warming to well below $2^{\circ} \mathrm{C}$ requires a transformation in the structure of global economic activity on a massive scale.

On their own, markets cannot deliver sufficient mitigation. Market failures, unaddressed and exacerbated by government failures, prevent an appropriate market response to the challenge of mitigating climate change. Some market failures can prevent needed long-term private investment even if public investments were sufficient and relative energy prices appropriate, justifying the use of financial policies as complements to fiscal policies.

A wide range of macroeconomic and financial policy tools can affect climate change and can be part of the package of measures for mitigation. While both international policy coordination and domestic policy action are key to addressing climate change, this paper focuses on the latter. There is a broad menu of policy options from which policymakers can choose. Fiscal policy options revolve around carbon pricing (explicit and implicit), spending and investment, and public guarantees. The needed transformation in the productive structure of the economy requires a change in the underlying financial asset structure, implying a key role for financial policy tools. These policies can be divided into those that aim to correct the lack of accounting for climate risks for financial institutions and those that aim to internalize externalities and co-benefits at the level of society. The former support mitigation by changing the demand for green and carbon-intensive investments, as well as relative prices. The latter work through similar channels but give rise to questions about appropriate policy tool assignment, trade-offs and political economy. Monetary policy tools may have a role to play. Some options are within most central bank mandates (reflecting climate risks in largescale asset purchase programs or collateral frameworks), while others are more controversial (green $\mathrm{QE}$, credit allocation policies, adapting monetary policy frameworks).

More research is needed on the most effective policy mix for climate change mitigation, and the role of climate mitigation in the overall policy framework. While some macroeconomic and financial tools are clearly desirable and complementary, others may substitute for each other, giving rise to trade-offs. The literature is scarce on the desirable package of measures to address climate mitigation. The impact of macroeconomic and financial policies on climate change implies that macroeconomic policy frameworks can be designed with the explicit additional goal of achieving sufficient mitigation within the time frame imposed by the threat of climate change. This raises questions about the role of mitigation in the overall policy framework and interactions with other goals. Coordination among policy areas could be critical for mitigation, and this issue requires more research. 


\section{INTRODUCTION}

The challenge posed by climate change is unprecedented. The 2015 Paris Agreement, signed by 195 countries, entails holding the increase in the global average temperature to well below $2^{\circ} \mathrm{C}$ above pre-industrial levels and pursuing efforts to limit the temperature increase to $1.5^{\circ} \mathrm{C}$. We are not on this path yet. A recent report of the Intergovernmental Panel on Climate Change (IPCC 2018) warns that global warming is expected to reach $1.5^{\circ} \mathrm{C}$ between 2030 and 2052, and to continue upwards from there. Given extreme uncertainties, the climate may warm much faster, and the risk of catastrophic outcomes is rising.

This review focuses on the roles that macroeconomic and financial policies can play in climate change mitigation. Existing international agreements on climate change mitigation require a transition to low-carbon economy (IPCC 2018). The implied transformation of the economy is massive and unlikely to happen through the market alone, due to various market failures. There is hence a clear case for policy action, and policy authorities are increasingly probing their own role in the required transition. The focus has tended to be on energy policy and variants of carbon pricing policies (IMF 2019a), and less on other types of macroeconomic and financial policies. But emissions are high and rising, fossil fuels continue to dominate the global energy mix, and the price of carbon remains defiantly low. Other complementary policies will likely be needed. To spur discussions of what these policies could or should be, we first spell out the case for policy action, and then review the rapidly growing literature on the role of macroeconomic and financial policies in climate mitigation. The literature is complex and large, and for conciseness, we limit the focus of the review in several dimensions. Problems and causes leading to climate change are complex and interact with many earth systems currently affected by human activity, as discussed in Rockström et al. (2009) and Steffen et al. (2018). However, this broader perspective is beyond the scope of this paper. We focus on policies to reduce $\mathrm{CO}_{2}$ or greenhouse gas (GHG) emissions, leaving the discussion of adaptation policies aside. Moreover, we focus on nationally implementable policies, discussing the roles of international leakages, global coordination of policies, and differences across national income levels only briefly.

The review of the literature provides a menu of relevant macroeconomic and financial policy tools and instruments for climate change mitigation. We consider three categories of policy tools: fiscal, financial and monetary. Fiscal tools are instruments that directly affect the government budget and are implemented by fiscal authorities. Financial policy tools include financial regulation, financial governance and policies to enhance financial infrastructure and markets, whereas we include policies that make use of the central bank balance sheet in the monetary policy category. There are gray zones between these three categories, as we discuss. The review of the literature suggests fiscal policy tools such as taxes, subsidies and public investment, should be in the front line for internalizing climate change externalities, reaping the co-benefits of climate change mitigation and securing lowcarbon public infrastructure. The literature on how to design such fiscal tools is well developed. However, even if fiscal tools could be optimally implemented, our review of the 
case for policy action suggests they may not be enough in a world where climate distortions interact with other types of market and government failures, and where political economy considerations are important. Other complementary policy tools may be called for, notably to secure appropriate levels of private investment. Private as well as public investment will be needed to support the required transformation of the productive structure and relative price changes in the energy mix in the long term. Financial policy tools can help achieve the necessary private investments in green productive capital, infrastructure and R\&D. Ensuring that central bank balance sheets accurately reflect climate risks can play a supporting role, both by leading by example and through a market price impact when central bank asset portfolios are sizeable. The literature also contains proposals for more active roles for financial and monetary policy tools in spurring a shift from high to low-carbon private investment, although the appropriateness of such tools and their interactions with fiscal policy and political economy considerations require more analysis. ${ }^{2}$

The literature does not spell out an appropriate policy mix, making this a key area for future research. The question of the most effective policy mix for climate change mitigation remains relatively unexplored and is complex given the substantial uncertainties around climate change. Addressing it requires a clear understanding of whether various policies are complements or substitutes in their incidence on the climate. It requires an understanding of policy trade-offs and interactions, as well as political economy considerations. We briefly discuss these issues and make some tentative observations. Notably, fiscal policies and ensuring proper pricing of climate risk in financial institutions, financial stability frameworks and central bank portfolios and operations are for the most part likely to complement each other and should all feature in the policy package. The active use of financial and monetary policy tools to promote green private investments, in contrast, may in some cases substitute for fiscal instruments but could be justified as a second-best policy option. A better conceptual and practical understanding of how to mix and prioritize fiscal, monetary and financial policies to mitigate climate change requires attention in the literature.

\section{The review highlights the complexity of the policy challenge and the need for coordination of different policy areas for achieving mitigation efficiently and effectively.} Fiscal, monetary and financial policy tools for climate mitigation can to varying degrees interact with other policies and objectives, such as business cycle stabilization and price stability. The literature review highlights the need for coordination between and among different policy areas to ensure the effectiveness of the policy mix and an appropriate assignment of tools and goals. The literature is scarce on these issues, however, suggesting a fruitful area for research.

\footnotetext{
${ }^{2}$ While countries at different income levels face different mitigation challenges, these distinctions are complex and not considered here. The menu of policy options for mitigation operates on multiple levels (national/international, developing economy/advanced economy), making it difficult — and in some cases incoherent - to divide the discussion along income-level lines.
} 
Finally, political economy considerations are key for achieving effective climate change mitigation and an important area for further research. Political economy considerations are of first-order importance and at least as important for the achievement of effective climate mitigation as a conceptual understanding of the characteristics of the appropriate policy mix. New and innovative ideas on how to break political deadlocks on who should bear the burden of climate mitigation policies - both within and between nations - are in strong demand.

The paper proceeds as follows. Section II sets the stage by making the case for policy action. It briefly summarizes the current climate science, the economic cost of unmitigated climate change, and what we know about the economic transition necessary for climate change mitigation. It also briefly reviews why this transition does not take place through the market, and hence, the need for policy action. The literature on the role of macroeconomic and financial policy tools in climate change mitigation is reviewed in Section III. It divides policy tools into fiscal, financial and monetary tools, as defined above. The Section also briefly reviews other types of policy instruments. Section IV offers some tentative observations on the policy mix, policy framework and policy coordination for effective and efficient climate change mitigation. Political economy considerations are discussed in Section V, and Section VI concludes. The Appendix contains supporting material.

\section{Setting the Stage: The CaSe for Policy Action}

\section{A. Climate Science and the Cost of Climate Change}

There is a broad scientific consensus on the dominant role of human activity in driving global warming (IPCC 2014, IPCC 2018, USGCRP 2017, USGCRP 2018). Carbon dioxide emissions accumulated in the atmosphere have reached unprecedented levels (Figure 1), with human activities estimated to have caused a large majority of those emissions (IPCC 2018). Scientific projections suggest the associated climate change will continue to worsen over the $21^{\text {st }}$ century, with major impacts on natural systems and human activity.

Global warming is likely to reach $1.5^{\circ} \mathrm{C}$ between 2030 and 2052 as a baseline scenario (IPCC 2018). UNEP (2018a) estimates that current Nationally Determined Contributions

\section{Figure 1. Carbon Dioxide Concentration in the Atmosphere}

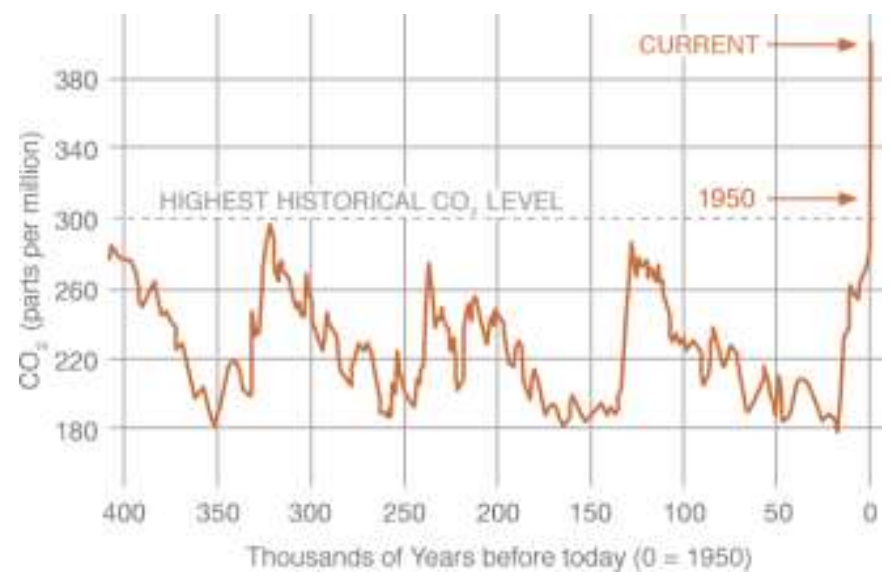

Source: NOAA. 
(NDCs) of the 2015 Paris Agreement signatories are currently consistent with a baseline global emissions trajectory that stabilizes projected warming at around $3^{\circ} \mathrm{C}$ by 2100 .

Non-linearities, tipping points and extreme complexity imply substantial uncertainty around this baseline. Risks and impacts are non-linear as temperature rises (IPCC 2014, 2018). Rising temperatures interact with other biophysical systems to create tipping points beyond which catastrophic outcomes can occur (Pigato, ed. 2019), including thawing of permafrost with release of vast additional amounts of GHGs, or the change of ocean streams. Climate change could generate entirely new climates (IPCC 2014). Human behavior could also reach tipping points in response, such as sudden onset of mass migrations (Rigaud et al. 2018). Rockström et al. (2009) find that three out of nine boundaries for maintaining the sustainable ecosystems necessary to support human civilization may have already been breached (see also IPCC 2018, WWF 2018, IPBES 2019).

Climate change affects economic outcomes through multiple channels. Rising temperatures, sea-level rises, ocean acidification, shifting rainfall patterns, and extreme events (floods, droughts, heat waves, wildfires) affect the economy along multiple dimensions, including through wealth destruction, reduction and volatility of income and growth (Deryugina and Hsiang 2014, Mersch 2018) and effects on the distribution of income and wealth (IMF 2017, Bathiany et al. 2018, De Laubier-Longuet Marx et al. 2019, Pigato, ed., 2019). These channels interact with each other in multiple ways, and are therefore challenging to model (Pottier 2016, Schneider 1997). ${ }^{3}$ The impacts of climate change are heterogeneous in terms of both geography (Hsiang et al. 2017, Tol 2019) and income levels (Hsiang 2019).

The broad consensus in the literature is that expected damages caused by unmitigated climate change will be high and the probability of catastrophic tail-risk events is nonnegligible. There is high uncertainty around climate damage estimates and many different estimates have been produced in the literature. Some studies point to large damages. Simulations presented in IMF (2019a) suggest so-called business-as-usual (BAU) temperature increases will reduce GDP for a typical low-income country by 9 percent in 2100 , taking into account current pledges of mitigation under the Paris agreement. Burke et al. (2015) estimate that climate change will reduce global GDP by 23 percent by 2100 , and GDP per capita by around 80 percent in South Asia, Southeast Asia and Sub-Saharan Africa based on an assumption of global warming of $3.7^{\circ} \mathrm{C} .{ }^{4}$ At the other end of the spectrum, Tol (2018) summarizes the literature on the economic impact of climate change as suggesting limited damages, but at the same time notes that the literature does not sufficiently account

\footnotetext{
${ }^{3}$ Section A of the Appendix reviews the limitations of Integrated Assessment Models, which are the dominant approach in the literature to assessing the costs of the damages caused by climate change.

${ }^{4}$ For alternative estimates, see Dietz and Stern (2015).
} 
for the impact of numerous important elements, including water resources, transport, migration, violent conflict and energy supply. ${ }^{5}$ The high uncertainty around estimates is not easily built into cost models (Hawkins and Sutton 2009, Hsiang and Kopp 2018, Stern 2016). ${ }^{6}$ Building on Kapp (1950), Pottier (2016) argues that the uncertainties are more important than the baseline scenarios, and that climate change is likely to uncover previously hidden interdependencies between the economy and natural systems, revealing new and potentially enormous disruptions and costs. There is growing agreement between economists and scientists that the tail risks are material and the risk of catastrophic and irreversible disaster is rising, implying potentially infinite costs of unmitigated climate change, including, in the extreme, human extinction (see, e.g., Weitzman 2009).

\section{B. What Needs to Be Achieved?}

\section{The appropriate response to climate change depends on whether a maximization or risk} management approach is taken. Early models employed for devising an optimal response to climate change have taken a dynamic growth maximization approach based on baseline cost estimates. In essence, the approach is to choose a GHG path that maximizes a discounted future expected path for growth. This path trades off the cost of mitigation (e.g., reduced growth up front due to paying more for renewable energy and costly investments in new productive capital and infrastructure) with the expected benefits (e.g., higher growth for future generations) (Nordhaus 2014). The uncertainty around forecasts and the distribution of outcomes is not considered. This makes sense if we can forecast the incidence of climate change with high precision, but this is hardly the case. Alternative proposals have been made for taking a risk management approach to climate change similar to "Value-at-Risk" frameworks increasingly followed in financial risk management and the "Growth-at-Risk" framework of Adrian et al. (2018) for monetary and macrofinancial policies (Aglietta and Espagne 2016, Raworth 2017, Svartzman et al. 2019, Krogstrup and Obstfeld 2018). Thus, instead of maximizing an unconstrained future discounted expected path of growth, a path for GHG emissions (also known as a climate pathway) would maximize discounted growth under the constraint that the risk of catastrophic irreversible climate change remains below an agreed percentile. Given what is at stake, it would be easy to argue that this percentile should be chosen to be as small as possible given historical emissions. ${ }^{7}$ The risk

\footnotetext{
${ }^{5}$ For this reason, Tol also concludes that "uncertainty about the impact of climate change $[\ldots]$ strengthens the case for GHG emissions reductions."

${ }^{6}$ Uncertainty also implies there could be some potential upside risks to climate change, although such gains would be temporary and specific to certain populations (IMF 2017).

${ }^{7}$ Another way of saying this is that no backstop exists in the event of catastrophic climate change (Aglietta et al. 2018). By contrast, global financial systemic risk always has a backstop via the existing network of central banks, which can act in coordination as lenders of last resort to safeguard the system. A non-zero risk of financial catastrophe can be accepted with the idea that time will heal the wounds, while climate catastrophe is final. On the uninsurability of climate change, see Chichilnisky and Heal (1993).
} 
minimization approach would necessarily be more constraining than the growth maximization approach. Given high uncertainties and large tails, the risk management approach implies that, from a social welfare perspective, GHG emissions should be reduced as fast and as much as possible (Aglietta and Espagne 2016). ${ }^{8}$

\section{Existing international agreements are based on the maximization principle and thus do not account for the extreme risk characterizing the climate change challenge. ${ }^{9}$ The} Sustainable Development Goals (SDGs), the Paris Agreement and the IPCC in different ways support limiting global warming to well below $2{ }^{\circ} \mathrm{C}$, defining a gradually-declining path for $\mathrm{CO}_{2}$ emissions to achieve this. The SDGs contain a commitment to limiting global warming as well as 16 other mutually interdependent goals (IPBES 2019, Bhattacharya et al. 2015, IPCC 2018). ${ }^{10}$ The Paris Agreement requires substantial reductions in $\mathrm{CO}_{2}$ and other GHG emissions over the next three decades, at most (IPCC 2018). Limiting global warming to well below $2^{\circ} \mathrm{C}$, and ideally around $1.5^{\circ} \mathrm{C}$, requires reductions of 45 percent in $\mathrm{CO}_{2}$ emissions by 2030 and reaching net zero by 2050. Currently, NDCs do not satisfy this aim.

\section{The lack of accounting for co-benefits of mitigation also implies that countries' existing} commitments may not go far enough. Some have pointed out that agreed paths of GHG emissions do not adequately take account of various co-benefits of mitigation action, now and in the future. Co-benefits of climate mitigation may for example include increased health through reduced air pollution, growth enhancing green innovation, preservation of nature and biodiversity, enhanced energy security and reduced climate-related migration (Parry et al. 2015, Arezki et al. 2016, Coste et al. 2019, Heine and Black 2019, IMF 2019a). ${ }^{11}$ It is challenging to model these co-benefits, and indeed they are rarely reflected in climate mitigation models. One approach to reflecting co-benefits is that of the Social Value of Mitigation Action (SVMA). Conceptually, the social value accounts for and encompasses all aspects of the interaction between human activity and nature, or in other words, all current and future co-benefits as well as costs and side effects of taking current mitigation action. Markets cannot price such a social value, which is instead suggested to be determined

\footnotetext{
${ }^{8}$ Note that the difference between the two approaches is not in the discounting of future generations. Even if we only cared about current generations, the risk management approach implies a limitation of GHG emissions that is at least as restrictive as the maximization approach. Indeed, minimizing the risk of catastrophic outcomes implies a need to decarbonize the economy as rapidly as possible, whereas the maximization approach may, under some parameter assumptions, only require a gradual reduction in emissions.

${ }^{9}$ Another notable initiative is the Coalition of Finance Ministers for Climate Action, launched in April 2019 at the Spring Meetings of the IMF and the World Bank (World Bank 2019a, 2019b and 2019c).

${ }^{10}$ Some SDGs may be partly contradictory, however. For example, SDG no. 8 (Decent Work and Economic Growth) may, under some circumstances, be inconsistent with SDGs no. 11 to 15 (Sustainable Cities and Communities, Responsible Consumption and Production, Climate Action, Life Below Water, Life On Land).

11 The main effects of low-carbon investments are learning-by-doing and positive spillovers on technological change (i.e., Schumpeterian innovation waves: Acemoglu et al. 2012, Stern 2015, Bramoullé and Olson 2005).
} 
collectively, e.g., through a political process. A collective agreement on a social value of mitigation would in turn allow for defining a set of so-called notional prices (or shadow prices) of mitigation action. The exact implications for an "optimal" path of GHG based on the SVMA are less clear, but attempts at operationalizing it for policy have been considered in the literature (see Box 1).

\section{Box 1. The Social Value of Mitigation Action (SVMA)}

The social value of mitigation action (SVMA) is the economic and environmental value of climate change mitigation actions and related economic and non-economic co-benefits (Hourcade et al. 2018, UNFCCC 2016a, Article 108, High-Level Commission on Carbon Prices 2017). The SVMA highlights the potentially substantial underpricing of cobenefits of carbon mitigation, in addition to the benefits of reducing carbon emissions. The SVMA can also help introduce a market for mitigation assets, compensating for its absence.

Two key concepts in the economics of climate change are the social cost of carbon (SCC) and the shadow price of carbon (SPC). The SCC can be defined as the net present social value of incremental damages (e.g., to agriculture, health) of an additional ton of $\mathrm{CO}_{2}$ emissions along an optimal emissions scenario. It is expressed in monetary units, and usually reflects worldwide damages. The shadow price of carbon (SPC) is a theoretical price used for business planning and investment. It adds a hypothetical surcharge to market prices for goods or services that involve $\mathrm{CO}_{2}$ emissions in their production.

The main proposition behind the SVMA is that the production possibility frontier (PPF) may be moving and path dependent, rather than fixed. Based on this proposition, the SVMA augments the conventional concept of the SCC by incorporating various co-benefits of mitigation action that impact social welfare (e.g., health co-benefits, the outward move in the PPF, and economic and technological spillovers) into the benefits of a ton of avoided GHG emissions along a given development trajectory.

To understand why the SVMA enables the incorporation of mitigation co-benefits, it must be compared to the SCC and the SPC. If the economy is not at the PPF, the relation between the SCC, the SPC and the explicit carbon price is not straightforward and requires the investigation of synergies between climate change mitigation and development (Hourcade et al. 2015). Early mitigation action can have a positive impact on future PPFs through two main channels: learning-by-doing effects that reduce the future cost of emissions reductions (Bramoullé and Olson 2005, Vogt-Schilb and Hallegatte 2014); and the contribution of the low-carbon transition to Schumpeterian waves of innovation, which moves the PPF outward (Stern 2015). An explicit carbon price that is lower than the SVMA is not the appropriate ex ante signal to trigger more ambitious decarbonization paths, as development paths vary in terms of both the quantity and quality of growth. This reflects structural features of different growth paths that result from transformation processes supported by various policy mixes (technical standards, building codes, public procurement standards, loan subsidies, public guarantees, infrastructure and R\&D, etc.). Crucially, these policy mixes include price policies, but are not restricted to them, since price levels depend on the growth path and the growth path depends on political decisions (Drèze and Stern 1990). The SVMA incorporates all social welfare co-benefits of climate change mitigation, from health benefits to shifts in the PPF through technological and economic spillovers. ${ }^{\prime \prime}$

Alternatively, the SVMA can be seen as the difference between the private and social return on low-carbon investments. In order to narrow this gap, a credible commitment to a stable shadow price of carbon is needed.

Operationally, the SVMA could be embedded in mechanisms that reward economically viable low-carbon choices. For example, the SVMA could be used to calibrate public guarantees, with governments of advanced economies using a globally determined SVMA within the range of values given by the IPCC for the marginal costs of carbon for a $2^{\circ} \mathrm{C}$ target and governments of developing countries using a domestic SVMA for the proportion of guarantees they would be willing to provide (Dastupta et al. 2019). Calibration of guarantees for cross-border investment based on a common notional price for avoided GHG emissions could help hedge against the fragmentation and arbitrariness of low-carbon initiatives. Alternatively, carbon assets could be issued when emissions reductions resulting from a project are realized and certified.

${ }^{1 /}$ Internalizing both climate and non-climate benefits of mitigation into a carbon price would not be appropriate, as the outcome would be an even higher gap between optimal and politically feasible carbon prices (see IMF 2019a). 


\section{Existing global commitments nonetheless imply a massive transformation in the} structure of global economic activity. In addition, the implied transition must be achieved within a short time frame. The IPCC (2018) finds that by 2030, GHG emissions must be 45 percent lower than their levels in 2010 to limit global warming to $1.5^{\circ} \mathrm{C}$. The challenge is compounded by the fact that emissions are still increasing.

\section{The transition requires changes in relative prices as well as large scale public and} private investments. It requires widespread adoption of new technologies and practices, changes in consumer behavior, changes in production and land use, agricultural processes and enhanced climate-driven innovation (IPCC 2018). The literature does not offer views on how future transformed societies will look, whether they will require a lower level of consumption per capita and what types of goods will be produced and consumed. This will depend on unpredictable technological innovation, and therefore lies beyond the scope of this literature review. But it is clear that to achieve the required transition and spur the necessary innovation, relative prices of fossil fuels will have to increase for energy consumers. In addition, there will have to be massive investments in low-emission infrastructure, buildings, $\mathrm{R} \& \mathrm{D}$ and productive capital to complement and support the necessary relative price changes. Relative price changes and investments are complements, not substitutes. Economic agents' ability to change their behavior in response to changing relative energy prices depends on the availability of alternative choices of energy. This availability in turn depends on the existence of supporting infrastructure for delivering and making use of alternative energy (Fay et al. 2015). Investments will have to be both public and private in nature. ${ }^{12}$

\section{Why Is Mitigation Not Taking Place via the Market?}

\section{A set of market and governance failures prevent the required transition from taking} place in time via the market. Below, we briefly review the key market and government failures that prevent the desirable outcome in response to climate risks. Market failures justify policy action and underpin, implicitly or explicitly, the different policy proposals we review in the next Section. ${ }^{13}$ Government failures shed light on why this policy action has not yet taken place, and we discuss some of these in Section V.

Climate change can be seen as a negative externality of production and/or consumption of carbon-intensive goods (e.g., Solow 1971). An externality is the effect of production or consumption on agents who do not participate in the production or consumption decision. In the presence of externalities, the private cost of a resource does not coincide with the social cost, and/or the private profit does not coincide with the social benefit. Market prices do not reflect the social cost of carbon, resulting in substantial negative externalities from GHG

\footnotetext{
${ }^{12}$ Carbon dioxide removal will also likely be required to limit global warming to $1.5^{\circ} \mathrm{C}$ (IPCC 2018).

${ }^{13}$ The High-Level Commission on Carbon Prices (2017) provides a comprehensive overview of market failures going beyond simple externalities.
} 
emissions (Pigato, ed., 2019). Moreover, individual choices, e.g., overconsumption, will not reflect externalities.

Alternatively, climate change mitigation action can be seen as a public good, the value of which can be viewed through the prism of the concept of SVMA described above (see also Box 1). This is a much broader and more encompassing, but also more complex, conceptual approach. Because climate change stems from interdependencies between human activities and natural systems, the SVMA prism implies a host of non-market interdependencies and interactions beyond the effect of carbon emissions on future climate, discussed as co-benefits of mitigation above.

The externalities and SVMA perspectives both suggest that markets underprovide mitigation. Markets do not take account of various externalities of GHG emissions and cobenefits of mitigation, and hence over-emit GHGs (Solow 1971), or underprovide mitigation investment (Aglietta et al. 2018). Further, government or collective action to correct market inadequacies may be hampered by what we refer to as government failures. We summarize specific mechanisms below.

\section{Market failures include different variants of:}

Common pool and free rider problems. Local entities may lack incentives to adequately mitigate through markets as climate stability benefits accrue mainly to other actors, resulting in free rider behavior (the well-known prisoner's dilemma).

Time inconsistency or impatience that leads to short-termism. Climate risk is characterized by the existence of a "tragedy of the horizon," as the catastrophic impacts of climate change will be felt beyond the traditional horizons of market participants (Carney 2015, Andersson et al. 2016). Prices may not reflect the long-term benefits of mitigation. Indeed, low-carbon investments may be particularly unattractive to investors, as they are characterized by two major sources of risk that differentiate them from other long-term investments: uncertainty around their ability to deliver carbon abatement, and uncertainty around the future value of avoided emissions (Aglietta et al. 2015).

\section{Governance problems and interactions with regulation and accounting standards} can amplify both common pool problems and short-termism in finance, hampering the finance of long-term uncertain investments (Admati 2017, Persaud 2015).

Incomplete and imperfect capital markets. Imperfect information may give rise to credit rationing (Stiglitz and Weiss 1981). Private investment in productive capital and infrastructure faces high upfront costs and significant uncertainties that cannot always be priced. Investments for the transition to a low-carbon economy are additionally exposed to important political risks, illiquidity and uncertain returns, depending on policy approaches to mitigation as well as unpredictable technological advances. Markets for 
trading these risks are impaired by incomplete information and knowledge as well as political uncertainty (High-Level Commission on Carbon Prices 2017).

Economies of scale and market power. Recent studies show that market power has increased in some sectors and some countries, which in turn may reduce incentives to invest in new capital (IMF 2019b).

\section{Government Failures}

Market failures interact with government failures. When markets are not providing the desirable outcome due to market failures, this makes the case for government intervention in markets. This role of government, however, is impeded by a set of public coordination or governance failures that are very similar to those affecting markets. Notably:

Common pool and free-rider problems. Similarly to the market failure discussed above, national and local levels of governments may lack incentives for climate mitigation action, since the benefits of these mostly accrue to citizens of other jurisdictions or countries (IMF 2019a). The interdependence between countries' mitigation actions thus generates key global spillovers and international coordination problems.

Collective action and capture by powerful interest groups. Political agendas can be bought. Economic agents gaining from the status quo may have the incentive, the means and the ability to coordinate targeted lobbying of government and influencing media, while those who would gain from changing the status quo are many with little incentive to respond individually and little ability to coordinate (Olson 1977). ${ }^{14}$

Time inconsistency and inability to commit. Democratically elected governments are subject to election cycles and can have limited ability to make long-term commitments (Persson and Tabellini 1999, Brunner et al. 2012, Helm et al. 2003).

Together, market and government failures constitute a web of interlocking interactions that complicate the task of addressing climate change. Below, we review specific proposals for macroeconomic and financial policies for climate change mitigation. When possible, we relate specific proposals to the mitigation need and the market failure they address. We briefly discuss government failures in the context of political economy considerations in Section V.

\footnotetext{
${ }^{14}$ There is ample empirical evidence of capture (Chang 2006, Hallegatte et al. 2013, Rodrik 2014).
} 


\section{Macroeconomic and Financial Policies for Climate Change Mitigation}

The theoretical benchmark "first-best" response to climate change in the literature comprises a path of taxes on emissions combined with subsidies to $R \& D$, as laid out in Stern (2006). The case for using a much broader set of tools rests on the fact that the problem of climate change is much more complex. There are many other market distortions and externalities, as well as interdependencies, tipping points and high uncertainty, as discussed above. Moreover, political economy considerations complicate the policy response and make some tools more appropriate than other based on political rather than conceptual considerations.

This Section presents the literature on the roles of fiscal, financial and monetary policies in climate change mitigation. Fiscal policy tools relate to the government budget and fiscal authorities. Macroprudential, financial regulatory, governance and financial market development policies are considered under the general heading of financial policies. Under the heading of monetary policy instruments, we consider policies relating to the central bank balance sheet, such as collateral policy, asset purchases and commercial banks' access to central bank balance sheets. We find this categorization of policies useful, but others could be chosen, for example along policy authority lines. Under our categorization, policy authorities can be responsible for enacting policies from several areas (e.g., central banks can be responsible for both macroprudential and monetary policy instruments).

The focus of policies to affect private behavior is on price-based, as opposed to quantity-based, interventions (ESRB 2016). Price-based interventions are at the core of most policy tools that aim to change private behavior, and more widely envisaged in the literature on climate policies. These types of policies aim at leveraging market mechanisms to achieve greater efficiency in the allocation of resources and costs of mitigating climate change. Quantity-based interventions - or so-called "command-and-control" policiesinvolve constraints on the quantity of energy consumption or GHG emissions through laws, regulations, standards and enforcement, with a focus on effectiveness rather than efficiency. While not considered here, quantity-based interventions may be well suited for the risk management approach under great uncertainty and high tail risks. ${ }^{15}$ We briefly describe a quantity-based financial policy option in Section III-B.

The review offers a list of potential policy instruments and considers pros and cons. Table 1 summarizes these policies and hence provides a map of the state of play of the literature. We also offer some tentative considerations about the policy mix and policy coordination in Section IV, while central political economy considerations are discussed in Section V.

\footnotetext{
${ }^{15}$ An example of a quantity-based policy is the proposal by the French High Council on Climate Change to make carbon budgets binding on all laws (Haut Conseil pour le Climat 2019).
} 
Table 1. Macroeconomic and Financial Policy Tools for Climate Change Mitigation

\begin{tabular}{|c|c|c|c|}
\hline \multirow{4}{*}{ Fiscal Policy Tools } & Carbon pricing, regulations & $\begin{array}{l}\text { National carbon taxes, cap-and-trade (CaT) and emissions } \\
\text { trading systems (ETS), emission or energy efficiency standards }\end{array}$ & $\begin{array}{l}\text { Sweden carbon tax, California CaT, EU ETS, } \\
\text { national feebates, EU regulations }\end{array}$ \\
\hline & Public spending and investment & Public investment, social spending, lower labor or capital taxes & EU Infrastructure Investment Plan \\
\hline & Public-private partnerships & $\begin{array}{l}\text { Partnership between private sector, government, } \\
\text { development bank, long-term institutional investor }\end{array}$ & $\begin{array}{l}\text { China Development Bank-Urban } \\
\text { Development Investment Corporation }\end{array}$ \\
\hline & Public guarantees & $\begin{array}{l}\text { Loan commitments, credit or cash flow guarantees, multi- } \\
\text { sovereign guarantees }\end{array}$ & $\begin{array}{l}\text { World Bank Multilateral Investment } \\
\text { Guarantee Agency (MIGA), European } \\
\text { Investment Fund guarantee schemes }\end{array}$ \\
\hline \multirow{5}{*}{ Financial Policy Tools } & $\begin{array}{l}\text { Redressing underpricing and lack of transparency of } \\
\text { climate risks }\end{array}$ & $\begin{array}{l}\text { Gathering climate-related financial data, climate-related risk } \\
\text { disclosures, taxonomy of green assets, climate-related stress } \\
\text { tests, macroprudential tools }\end{array}$ & $\begin{array}{l}\text { Bank of England Supervisory Statement on } \\
\text { Climate Change, France Article } 173 \text { of Energy } \\
\text { Transition Law, Banco Central do Brasil, China } \\
\text { mandatory disclosures }\end{array}$ \\
\hline & $\begin{array}{l}\text { Reducing short-term bias and improving governance } \\
\text { frameworks of financial institutions }\end{array}$ & Prudential reforms, corporate governance reforms & Promotion of ESG criteria \\
\hline & & & \\
\hline & Supporting the development of green financial securities & $\begin{array}{l}\text { Standardized taxonomy of green assets, low-carbon indices, } \\
\text { platforms and active issuance by authorities }\end{array}$ & PBoC national-level green bond taxonomy \\
\hline & $\begin{array}{l}\text { Actively promoting climate finance using financial } \\
\text { regulatory tools }\end{array}$ & $\begin{array}{l}\text { Green supporting and brown penalizing factors in capital } \\
\text { requirements, international requirements of min. amount of } \\
\text { green assets on balance sheets, notional carbon prices }\end{array}$ & $\begin{array}{l}\text { PBoC macroprudential policy framework, } \\
\text { Banque du Liban reserve requirements }\end{array}$ \\
\hline \multirow{3}{*}{ Monetary Policy Tools } & $\begin{array}{l}\text { Integrating climate risk analytics into collateral } \\
\text { frameworks, central bank portfolio management, and QE }\end{array}$ & $\begin{array}{l}\text { Developing own risk assessments, ensuring climate risks } \\
\text { appropriately reflected in central bank asset portfolios }\end{array}$ & $\begin{array}{l}\text { Bank of England, Bank of Japan, EIB bonds, } \\
\text { Bangladesh Bank, DNB, Norges Bank }\end{array}$ \\
\hline & Green QE and collateral frameworks & $\begin{array}{l}\text { Better access to central bank funding schemes for banks that } \\
\text { invest in low-carbon projects, central bank purchases of low- } \\
\text { carbon bonds issued by development banks }\end{array}$ & \\
\hline & Credit allocation policies & $\begin{array}{l}\text { Central bank credit allocation operations, adapting monetary } \\
\text { policy frameworks }\end{array}$ & PBoC, Res. Bank of India, Bangladesh Bank \\
\hline
\end{tabular}




\section{A. Fiscal Policy Tools}

Fiscal policy has a natural role to play in achieving climate mitigation. As noted above, the first-best theoretical benchmark policy response is fiscal, using Pigouvian taxes on emissions at the source of emissions (or equivalent subsidies for capture and storage of GHGs) and subsidizing R\&D (Pigou 1932, Stern 2006). Taking an SVMA perspective, this approach can be combined with subsidies of positive co-benefits of mitigation actions, which can also help shift consumption and investment patterns. Fiscal policy tools can also help secure appropriate public spending and investment. Existing policy frameworks take the goal rather than tools as starting point, however, focusing on pledges to limit emissions, with signatories of the Paris Agreement having submitted such pledges. Key practical issues include which policies, notably carbon tax trajectories, are needed to implement these pledges, and how action can be scaled up at the international level (IMF 2019a).

A wide range of fiscal policy tools are available. Fiscal instruments fall into three broad categories: price policies (taxation, subsidies), spending and investment, and public guarantees. The three are closely linked. Price policies include carbon taxation and cap-andtrade schemes (IMF 2019a), subsidies for mitigation action, low-carbon investment subsidies, interest rate subsidies, feebates, tax breaks. Spending and investment tools include outright public investment, concessional loans from development banks and public investment funds. Public guarantees can help secure higher private-sector participation in public financing (IPCC 2018). While most mitigation investment will be private (e.g., improvements in energy efficiency, renewable power generation), some will be public (e.g., public transportation networks, expansion of the power grid to renewables sites, infrastructure for carbon capture and storage). We consider the different types of policies below.

Carbon pricing policies are central to climate change mitigation. Appropriately designed carbon prices are widely seen to be critical to any successful mitigation strategy (Lagarde and Gaspar 2019, Arezki and Obstfeld 2015, Farid et al. 2016). Carbon prices should reflect the environmental costs of carbon emissions, including climate change, but also local air pollution, traffic congestion, accidents, and road damage (IMF 2019a). They should also reflect co-benefits in terms of innovation and increased productivity growth (Aghion et al. 2009), as well as more sustainable agricultural, industrial and transport systems (see, e.g., Batini 2019 for an analysis of the gains from agri-food sector reform in France). The two main options for introducing carbon pricing are carbon taxation and cap-and-trade schemes. An important caveat is that many studies find that the costs of carbon emissions are highly uncertain and extremely difficult to quantify.

The literature sets out a set of principles for how carbon taxes can be implemented at the national level. The carbon tax proposal requires introducing a carbon tax at the appropriate level, which must equal the social cost of carbon amounting to damages caused by an additional ton of carbon emissions (Auffhammer 2018). IMF (2019a) stresses several 
dimensions of appropriate carbon pricing design: the comprehensive nature of emissions coverage; the gradual rise over time and predictability of carbon prices (to help mobilize lowcarbon technology investment); the alignment of carbon prices with mitigation objectives; and the exploitation of the resulting fiscal opportunities.

While the most commonly proposed measure is a carbon tax, removing subsidies may be equally important (Rudebusch 2019, Climate Leadership Council 2019). Carbon subsidies remain pervasive in the global economy, making their removal equally urgent. Although uncertain, global implicit subsidies stemming from undercharging for fossil fuels have been estimated to be of massive scale. ${ }^{16}$

There is evidence that carbon pricing can work to reduce emissions. Carbon taxes or emissions trading systems have been found to be effective at reducing carbon emissions and capable of generating significant fiscal revenues (Farid et al. 2016, IMF 2019a). Carbon pricing makes firms move toward the best-practice frontier (Coste et al. 2019), and firms are more innovative in clean technologies when they face higher fuel prices, with path dependence in the type of innovation (Aghion et al. 2015). Carbon pricing may also increase energy efficiency. There is evidence that countries with persistently low carbon prices are characterized by very low energy efficiency, ultimately forcing them to spend a larger share of national income on energy (Grubb et al. 2018).

Carbon pricing may not always be effective, however. Some studies point out that prices can be ineffective in triggering desired changes when low-carbon alternatives or long-term credibility are absent (Fay et al. 2015). A carbon tax may not be able to produce frontier innovation in the energy or automobile industry if other market failures such as long-term technology lock-in and short-termism in investments prevent this, for example leaving transportation consumers with little option but to pay the tax for fuel while not changing to more energy efficient options (which are not available) (Unruh 2000). If efficiency is low, a higher carbon price increase could help, but political economy considerations may prevent this (Fay et al. 2015, see also Section V).

Carbon taxation should be combined with redistributive spending components. While in principle the revenues from carbon taxation should be spent in a way that has the highest value for the population (Pigato, ed., 2019, Guillaume et al. 2011), experience suggests that political economy considerations are crucial for gaining public acceptance of carbon pricing

\footnotetext{
16 The estimated value of global 'pre-tax' fossil fuel subsidies is $\$ 400$ billion (IEA 2018). These estimates compare average end-user prices paid by consumers with prices that correspond to the supply costs. Going further and taking into account environmental costs like global warming and air pollution (i.e., 'post-tax' subsidies), estimates of global implicit fossil fuel subsidies are an order of magnitude larger, at $\$ 4.7$ trillion (Coady et al. 2019).
} 
policies (see Section V below). ${ }^{17}$ Carbon tax or subsidy reforms that only have a revenue component face a much lower probability of success (Fay et al. 2015, Ruggeri Laderchi 2014). By contrast, reforms that use carbon tax revenues (e.g., through reduced fossil fuel subsidies) to finance per-capita transfers have proved successful (Guillaume et al. 2011, Heine and Black 2019, see also Klenert et al. 2018). Recycling of carbon tax revenues may also increase economic efficiency (Goulder 1995). This underscores the importance of climate mitigation policy packages that contain both revenue and spending components (e.g., lower labor taxes; higher spending on social protection or public services, as well as spending on public investment).

\section{Spending and investment policies are also important for effective climate change} mitigation. Public procurement can help foster low-carbon innovation and generate economies of scale (High-Level Commission on Carbon Prices 2017). Green public procurement standards may also help increase the demand for lower-carbon industrial products (IEA 2017). Public infrastructure investments are particularly pertinent. As noted earlier, infrastructure investments can lock in the type of energy mix used, for example in public transport and urban infrastructures. Hence they can lock in carbon emissions for a long time. In the current low-interest rate environment, public infrastructure investments may be particularly effective, and can have additional justifications in terms of countering secular stagnation (Blanchard 2019).

There is a role for public-private partnerships (PPPs) in ensuring adequate investment. In countries that were selected for the IMF-World Bank pilot Climate Change Policy Assessments (CCPAs), public investment management systems have been a critical weakness, with issues related to insufficient legal frameworks for PPPs and project selection and costing (IMF 2019a). Arezki and Belhaj (2019) find that PPPs can, if properly designed and implemented, allow governments to improve infrastructure procurement and management while reducing public spending. A caveat is that recent attempts in the UK and recent research have highlighted potentially significant issues with PPPs (Innes 2018).

Finally, the issuance of public guarantees could play a major role in filling the lowcarbon investment gap. Proponents of this instrument argue that it could play a critical role in reducing risk perceptions for project developers, financial intermediaries, and savers with minimal fiscal cost (Dasgupta et al. 2019). This would enable the scaling up of low-carbon investment in developing countries and would leverage the capabilities of multilateral and national development banks, international and domestic banks and long-term institutional

\footnotetext{
${ }^{17}$ Carbon pricing can also be introduced through notional prices to address risks and political uncertainties around carbon prices. For instance, a notional price can be given to expected avoided emissions through a public guarantee mechanism, resulting in a pre-commitment to pay in case of partial or complete failure of a low-carbon project based on a given carbon value (Dasgupta et al. 2019).
} 
investors seeking large but safe and sustainable investments..$^{18}$ Guarantees could be multisovereign.

\section{SVMA-based approaches to public guarantees could facilitate low-carbon private}

investments. The large gap between the private and social returns on low-carbon

investments is likely to persist into the future, as future paths for carbon taxation and carbon pricing are highly uncertain, not least for political economy reasons. This means that there is not only a missing market for current climate mitigation as carbon emissions are currently not priced, but also missing markets for future mitigation, which is relevant for the returns to private investment in future climate mitigation technology, infrastructure and capital. To enable financial actors to lock in returns to mitigation investments that are commensurate with the social value of these investments - and hence facilitate their financing - Aglietta et al. (2015) propose that governments provide a tradable guarantee (a climate asset, or a certificate) ensuring a certain minimum politically-agreed return (a carbon price, the SVMA) that pays out when the investment leads to reduced emissions and these reduced emissions are certified (see also Dasgupta et al. 2019). Such a guarantee scheme would require the creation of independent verification agencies, which would play the key role of measuring and certifying the quantity of emissions reductions resulting from individual low-carbon investments. Proposals have also been made to make related climate assets eligible for refinancing by the central bank, which would further improve access to funding for such investments. This would commit the government more credibly to honor such guarantees, as they would already be on the consolidated budget. This proposal has elements of financial as well as monetary policies, and raises questions about the credit allocation activities of central banks and consistency with central bank mandates. We address those questions in more detail below. ${ }^{19}$

\section{B. Financial Policy Tools}

\section{Policies that affect financial markets and financial institutions - referred to here as financial policies - can help mobilize private investments. Reflecting the central role of finance in climate policy, Article 2 of the Paris Agreement calls for "making finance flows consistent with a pathway towards low greenhouse gas emissions and climate-resilient}

\footnotetext{
18 The rationale behind public guarantees is that the gap between politically viable carbon prices and those required for agents to switch to low-carbon investments is likely to persist (Dasgupta et al. 2019). The needed carbon prices may also be exacerbated by the switching price of carbon that results from market failures in credit creation and allocation (Campiglio 2016). Instruments to overcome carbon pricing issues (feed-in tariffs, long-term power purchase agreements) face the risk of loss of cost control due to a lack of consistency with other policy instruments (García-Álvarez et al. 2017, Bhattacharya et al. 2015, Lecuyer and Quirion 2013). Public guarantees have historically helped financially support projects that serve the public interest but are perceived as too risky because of their long duration, by rewarding investments upfront in a way that is decoupled from volatile annual public budgets (Dasgupta et al. 2019).

19 This mechanism would have a smaller budget cost than a credit subsidy, as some of the guarantees may not lead to a payment.
} 
development" (UNFCCC 2016b). Finance is a key enabler and driver of technological transformations (Dasgupta, forthcoming). Public investments are required, but private investments in productive capacity, infrastructure and $R \& D$ are key. These will be needed on a large scale to drive the required transformation of economic activity (Sachs et al. 2014, Villeroy de Galhau 2015). Fiscal policy tools for boosting such private investments may not be enough or efficient given the prevalence of distortions and structural and political impediments discussed earlier. While carbon taxes can discourage continued investments in existing, carbon-intensive capital, facilitating low-carbon investment also requires addressing short-termism in the face of long-term uncertainty as well as issues of incomplete or absent financial markets. Below, we discuss these issues and survey relevant financial policy tools.

\section{Several types of financial policies have been proposed to support private climate}

finance. We distinguish between financial and monetary policies, dividing the former into four categories. ${ }^{20}$ First, financial policy tools that redress possible underpricing and lack of transparency of climate risks in financial markets and regulatory prudential frameworks; second, policy instruments that can help reduce the short-term bias and improve governance frameworks of financial institutions; and third, tools to support the development of markets for green financial instruments. These first three categories largely contain policies that aim to more accurately reflect climate risks in the application of existing policy tools and the development of markets and do not propose adding new goals to existing tools. These proposals are hence relatively uncontroversial, as they do not bring up complicated issues of policy trade-offs. The fourth category, on the other hand, goes further and comprises tools that actively shift incentives toward climate finance. Proposals in the fourth category therefore raise issues of policy trade-offs and policy considerations, which we discuss.

\section{Redressing the mispricing and increasing the transparency of climate risks}

Climate-related financial risks are potentially large. Climate-related financial risks can be divided into three categories:

Physical risks. These include the implications of droughts, floods or storms for the value of investments and productive capacity. Physical risks in turn can have implications for financial regulation and supervision activities (Prudential Regulation Authority 2015, Batten et al. 2016, Bank of England 2019a).

Transition risks. Transition risks are related to the transition to a low-carbon economy. The transition will require leaving a large share (around two-thirds, on average) of oil, gas and coal reserves in the ground, implying potentially large balance sheet write-offs for the firms that own them (Meinshausen et al. 2009,

\footnotetext{
${ }^{20}$ Dikau and Volz (2019a) use a different categorization, dividing green finance policies into five areas: microprudential regulation, macroprudential regulation, financial market development, credit allocation, and central bank soft power and guidelines.
} 
McGlade and Elkins 2015, and Bank of England 2019a). Uncertainty and volatility of the returns to investment in the production and use of new energy sources, notably due to uncertainty about public support and investments in public infrastructure, are also important transition risks (these risks are also referred to simply as policy or regulatory risks). Asset stranding and other transition risks could affect the market valuation of implicated firms, with potential spillover effects on investors through financial interconnectedness (Campiglio et al. 2018, ESRB 2016, Battiston et al. 2017, Carbon Tracker 2013).

Liability risks arise from the potential impact of legal action taken by parties who are adversely affected by climate change against firms and other economic agents that are held responsible, with potential implications for the latter's insurers (Carney 2015).

Climate-related financial risks are unique. They stem from the far-reaching impact, unforeseeable nature, irreversibility, and dependency on short-term actions (NGFS 2019). Climate risk is systemic, as it has the potential to affect the entire economy and financial system.

Climate risks may not be adequately reflected in financial balance sheets and assets prices. Financial markets may underprice risks due to the Tragedy of the Horizon (Carney 2015): the traditional horizon of most banks and investors may be shorter than that at which the full materialization of climate risks occurs (Carney 2019). Moreover, financial risks are often priced based on historical distributions of outcomes, but this approach does not capture climate change risks, which have no historical precedents. Past weather patterns or energy prices are not informative for what is to come. Pricing of climate risks must rely on the science of climate change, requiring a whole new risk pricing framework and new competencies of financial risk pricing experts. There is empirical evidence of underpricing of climate risks in financial markets (Hong et al. 2019, Addoum et al., forthcoming, Sowerbutts 2016, BlackRock Institute 2015). Ensuring appropriate pricing of climate-related risks requires more research on pricing techniques.

Gathering and disseminating relevant climate data could enhance climate risk assessment in financial regulation and stress tests, as well as carbon pricing and the development of green financial instruments. There is evidence that the data needed to manage climate financial risk are complex and fragmented, suggesting a role for regulators in supporting the creation of agencies responsible for collecting, validating and disseminating climate-relevant data (Battiston 2019).

A better reflection of and accounting for climate risks can contribute to scaling up
green market finance. Non-transparent and possibly underpriced climate risks imply that
investments subject to climate-related risks are effectively subsidized in finance. This would
tend to hinder the reallocation of capital from climate-risky assets toward the financing of
low-carbon investment projects (King 2013, Spencer and Stevenson 2013, Bhattacharya et al. 
2015, Mazzucato 2013a). Studies find that another hindrance to the financing of low-carbon projects is that they typically have high upfront capital costs and suffer from high investment risks (Nelson and Shrimali 2014, Schmidt 2014).

\section{Disclosure requirements can help support and improve pricing and transparency of} climate risks. Recent and ongoing policy initiatives include the formation of the Financial Stability Board's Task Force on Climate-related Financial Disclosures (TCFD), and the EU Council Position Agreement on low-carbon benchmarks and disclosure requirements.

Another example is Article 173 of the French Energy Transition Law, which requires firms to disclose or provide an adequate explanation for climate-related risks (NGFS 2019). ${ }^{21} \mathrm{~A}$ number of central banks are explicitly communicating on the need for improved climate risk pricing techniques and climate risk transparency in financial assets and balance sheets (e.g., Bank of England 2019a). Currently, the TCFD encourages firms to use its recommendations as a framework for disclosing climate-related risks but does not require them to do so.

Standardizing climate-related disclosures and making them mandatory could provide a major impetus to improved pricing of climate risks. Rey (2019) takes a step beyond transparency of balance sheet risks and calls for the development of a range of regulated ecological investments that are accessible to a large number of investors and are transparent. ${ }^{22}$

\section{Climate risks have implications for financial stability within existing financial stability frameworks, pointing to a role for prudential regulation. Recent work from central banks stresses that climate-related risks fall squarely within the supervisory and financial stability mandates of central banks and supervisors (Cœuré 2018, NGFS 2018, see also Rudebusch 2019, Scott et al. 2017, Dietz et al. 2016, Volz 2017), but are currently not sufficiently addressed.}

Capital adequacy requirements could better reflect climate-related risks. Basel capital adequacy requirements focus on reducing systemic risks of depository institutions, which in turn can affect real economic outcomes (D’Orazio and Popoyan 2019). Under the new Basel III prudential framework, capital and liquidity requirements do not explicitly include climaterelated risk assessments for bank exposures (BCBS 2016, ESRB 2016). This means that taking on climate risk may be much "cheaper" for regulated institutions in terms of capital requirements than what is desirable from the point of view of the stakeholders of the individual institution as well as well from a systemic financial stability perspective.

\footnotetext{
${ }^{21}$ Another example is a recent report on the measurement of physical climate risk analysis in finance (Institute for Climate Economics 2018).

${ }^{22}$ Such investments would require large firms to provide information on their audited environmental balance sheets. Firms would assess the environmental footprint of their entire value chain, this information would be made public, and decarbonization would be integrated into the employees' objectives. Rey suggests that, should institutional investors fail to demand rapid quality control from firms in which they invest, regulators should require such practices from firms and tax investors' non-decarbonized portfolios.
} 
Macroprudential policies could internalize systemic climate risk. Current prudential frameworks generally do not explicitly take climate-related risks into account, and could be adapted to incorporate such risks within existing mandates, conditional on a thorough assessment of the financially systemic nature of climate risks (Monnin 2018, Schoenmaker and Tilburg 2016). Tools could include reserve, liquidity and capital requirements, loan-tovalue ratios, and caps on credit growth, as well as sectoral capital buffers targeting credit to particularly climate-exposed sectors (for example following macroprudential policy design as in Galati and Moessner 2017, Cerutti et al. 2017). Again, a challenge is to correctly price climate risks over given horizons and measure these against traditional risks. As an example of incorporating climate risks in prudential regulation, Banco Central do Brasil requires that commercial banks incorporate environmental risk factors in capital need calculations (Banco Central do Brasil 2011).

Stress tests can incorporate climate risk aspects (ESRB 2016, NGFS 2019). Climaterelated stress testing can easily be included in existing financial stability frameworks. The stress-testing research and macroeconomic modeling that would be required to measure climate-related financial risks could also help assess whether climate-related financial risks should be used more generally in the calibration of macroprudential policies as discussed above (Campiglio et al. 2018). The Bank of England has recently announced that the UK Prudential Regulation Authority will require UK insurers to assess how they would be impacted in different physical and transition risk scenarios (Bank of England 2019a). The Bank of England, moreover, is conducting stress tests using climate scenarios (including both physical and transition risk) for insurance companies (Bank of England 2019b), and plans to conduct a climate stress test for financial institutions in 2021 to help mainstream climate risk management (Bank of England 2019c). ${ }^{23}$ The DNB has also conducted preliminary transition risk stress tests for the Netherlands (Vermeulen et al. 2018).

The effectiveness of price- and transparency-based financial policies to improve capital allocation has been questioned, however. Christophers (2017) argues that financial markets suffer from numerous market failures, such that the behavioral response of markets to pricebased policies is uncertain and less likely to succeed.

\section{Reducing short-term bias, improving governance frameworks of financial institutions}

Reform of governance in the financial system may potentially strengthen incentives for financing socially desirable investments. According to costly trade theory, long-term assets are prone to mispricing due to capital needs and the risk of arbitrage (Shleifer and Vishny 1990, 1997). Besides short-term bias due to short horizons and uncertainty, there are examples of how governance issues, such as frequent performance reporting requirements, lack of internalization of risk taking, limited liability, tax subsidies to leverage, and other

\footnotetext{
${ }^{23}$ Furthermore, in April 2019 the Bank of England announced that it would start disclosing how it integrates climate-related financial risks across its balance sheet and processes (Bank of England 2019d).
} 
issues affect finance and lead to less socially desirable decision making in financial institutions (e.g., Admati 2017, Aglietta et al. 2018, EU High-Level Expert Group on Sustainable Finance 2018). Risk taking may also be elevated due to the too-big-to-fail problem in financial markets. Addressing such problems could help improve access to longterm climate finance, although a clear case remains to be made in the literature.

\section{Supporting the development of markets for green financial securities}

Green financial securities are increasingly in demand from investors bound by specific criteria (e.g., Environmental, Social and Governance [ESG] criteria, or a policy of diversification away from fossil fuels, like that of the Government Pension Fund of Norway). Issuers of such securities should thereby in theory benefit from better access to financing. ${ }^{24}$ While the impact needs to be explored further, preliminary evidence suggests that green bonds may improve firms' environmental footprint when bonds are certified by independent third parties, highlighting the potential importance of certification in the green bond market (Flammer 2019).

The trade in green financial securities is hampered by lack of transparency, standardization and missing markets. Due to poor transparency and lack of standardization of reporting of climate risks and the price of climate co-benefits, securities traded in international financial markets cannot be easily priced based on climate risk and climate mitigation co-benefits. This results in low liquidity and turnover in such markets. Deeper and more liquid markets for green financial securities could help increase both the demand for and the supply of such assets, hence reducing the cost of financing climate mitigation investments.

Financial authorities can support the development of green bond markets through the development of platforms, information and active issuance. Many governments or agencies are already going down this path. The People's Bank of China ( $\mathrm{PBoC})$, for example, introduced the world's first national-level green bond taxonomy in 2015 (NGFS 2019).

Some proposals aim to support climate finance and markets internationally. Complementarily to the development of green securities markets, Rogoff (2019) calls for the creation of a World Carbon Bank. Bredenkamp and Pattillo (2010) propose to include the use of Special Drawing Rights (SDRs) in the financing of low-carbon funds.

Challenges remain as to how to define and certify credibly and transparently green securities, however, making this a market prone to lemons problems (Akerlof 1970). Perhaps as a result, green bond issuers do not consistently benefit from a coupon discount compared to traditional bonds with the same features (NGFS 2019). Examples of support for

\footnotetext{
${ }^{24}$ Green bonds could also help increase intergenerational burden sharing of climate mitigation costs (Sachs 2015, Flaherty et al. 2017, Orlov et al 2018).
} 
the development of green bond markets include the issuance by the PBoC in 2016 of a Guidance on Greening the Financial System, which aims to expand green finance beyond banking, and the PBoC's recent establishment of a task force to promote the standardization of green finance. More generally, governments increasingly issue green bonds for financing climate-related public investments. This may support these markets and increase liquidity. It is not clear that public issuance activity represents an increased amount of financing going into public climate-related investment yet, however, as investments that were taking place anyway may just have been relabeled and repackaged as green bonds rather than traditional bonds.

\section{Actively promoting climate finance using financial regulatory tools}

Regulation to actively increase demand by investors for climate mitigation investments should reduce the relative price of such investments. In conventional financial models with complete markets, perfect information and perfect substitutability of assets, the demand for specific assets does not matter for their relative price. Indeed, prices and returns in the commonly-used Capital Asset Pricing Model (CAPM) are based on covariances, with no role for the impact of changes in the investor base. However, markets do not generally live up to the assumptions of the conventional finance model. One reason is that the risks and benefits of low-carbon investments are highly uncertain, as discussed earlier. ${ }^{25}$ Moreover, the emerging literature on unconventional monetary policies shows changes in demand for and/ or supply of specific securities changes the relative prices of these securities in the markets due to frictions such as preferred habitat and segmented markets (Vayanos and Vila, 2009, Gagnon et al. 2011, Ball et al. 2016). If demand for low-carbon assets increases, this could increase their price through portfolio balance effects (and hence lower their financing costs). Potential synergies with carbon taxation exist, as evidence suggests green bond performance improves when carbon taxation is in place (McKibbin et al. 2017, Heine et al. 2018).

\section{Some proposals favor adjusting financial regulation to increase demand for green assets, beyond accounting for the implied risks. For example, the EU High-Level Expert Group on Sustainable Finance (2018) raised the prospect of introducing a "green supporting factor" and a "brown penalizing factor" in prudential rules that would increase banks' demand for financing green investments and reduce their demand for carbon-intensive investments. Alternatively, capital requirements on climate-friendly credits or green bonds can be lowered.}

\footnotetext{
${ }^{25}$ Low-carbon investments' risks are complex and partly unknown, as they stem from their ability to deliver carbon abatement as well as the future value of avoided emissions (Aglietta et al. 2015). As a result, the distribution of their returns is likely to be non-normal. This is inconsistent with the CAPM, which is only compatible with a Gaussian distribution of returns.
} 


\section{Climate mitigation-promoting regulatory tools have been implemented in some} countries. Banque du Liban differentiates banks' reserve requirement ratios depending on lending allocated to green projects (Banque du Liban 2010); the PBoC is incorporating green financing into its Macro-Prudential Policy Assessment framework (PBoC 2018). In advanced economies, the idea of introducing 'green supporting' and 'brown penalizing' factors in capital requirements may be gaining traction (EU High-Level Expert Group on Sustainable Finance 2018, Thomä and Hilke 2018). ${ }^{26}$ See also Tooze (2019).

\section{There are risks to employing existing financial prudential tools toward the aim of} climate finance. Campiglio et al. (2018) note that lowering capital requirements on bank loans to green sectors could undermine macroprudential policy goals and financial risk mitigation; climate-friendly prudential policies could prove too blunt if applied to entire sectors or firms, since firms may engage in a variety of activities whose carbon-intensity may differ considerably. Moreover, unilateral deviations from international prudential standards could weaken frameworks, open the door for unilateral deviations and tilt the playing field for international banking (IMF 2018). Indeed, the Basel Committee has consistently adopted an approach in which prudential rules are based only on risk considerations, to shield them from influences like industrial policy goals or political interference in banks' lending practices.

\section{New complementary regulatory tools to promote climate finance have also been}

proposed. To avoid policy trade-offs and the weakening of prudential regulation in addressing financial risks pointed out above, new regulatory instruments could be considered that could promote climate finance exclusively and as a complement to prudential regulation. For example, Aglietta and Espagne (2016) call for the introduction of international requirements of a minimum amount of 'green' assets on bank balance sheets. Rey (2019) is also an example of using regulation to enforce more green finance. Such proposals would be complementary to the development of green securities markets as discussed above. They may equally suffer from some of the challenges to transparency and certification related to the development of green securities markets. Moreover, how such proposals interact with, and complement or substitute for fiscal policies such as public guarantees should be addressed in future work.

\section{Monetary Policy Tools}

Monetary policy has not traditionally been considered relevant for long-term climate change mitigation efforts. Monetary policy is usually mandated to conduct stabilization policy while fiscal authorities are responsible for long-term structural and redistributive policies (both within current generations and across generations). Fiscal policies to internalize externalities and co-benefits, public investments and financial policies to

\footnotetext{
${ }^{26}$ There have been proposals for supervisory agencies to integrate ESG criteria into their work (European Commission 2017).
} 
appropriately account for climate risks are hence usually considered first in line with respect to climate change mitigation. However, appropriately accounting for climate risks in the balance sheet of the central bank may also be part of the first line of defense. Further, in a second-best world where political economy considerations may trump economic rationales and arguments, some argue for a role for monetary policy instruments to achieve climate stabilization, even if other tools would be better suited (Rozenberg et al. 2014), as we discuss further below.

Adaptation to climate change is clearly relevant for monetary policy. Climate change and mitigation policies are likely to increasingly affect the frequency and amplitude of supply price shocks, business cycles, risk and volatility. Higher temperatures may slow growth in different sectors (Colacito et al. 2018), spending on climate change resilience may hamper productive capital accumulation (Rudebusch 2019, see also Batten 2018). These factors in turn can affect credit spreads, precautionary saving, real interest rates and financial instability, all affecting inflationary pressures, to which monetary policy responds. Adaptation policies are not discussed further here, see Debelle (2019), McKibbin et al. (2017), Cœuré (2018), Lane (2019) and Rudebusch (2019).

Central banks are increasingly contemplating supporting roles of monetary policy in climate change mitigation. Central bank mandates often include contributions to general economic welfare in addition to price stability (Dikau and Volz 2019b). This general mandate can be interpreted to also include climate change mitigation considerations, given that primary objectives are met. Moreover, monetary policy tools can contribute to climate change mitigation, as described below. The redistributive role of monetary policy is increasingly being recognized and analyzed (Koedijk et al. 2018). The redistributive impact can be harnessed for secondary mandates, such as climate (Carney 2015, Cœuré 2018, Dikau and Volz 2019b), but this remains controversial and risky, as we discuss below. To date, only the PBoC has a dedicated policy to promote green finance via monetary policy (NGFS 2019).

The literature has pointed to ways in which monetary policy could actively support the transition to a low-carbon economy. These include adapting central banks' collateral frameworks, and using ESG criteria in their large-scale asset purchases (Cœuré 2018). Along the same lines, correct prices of climate risks can be reflected. Some have suggested taking it one step further and actively purchasing green assets or eliminating assets with high carbon intensity from central bank portfolios, beyond what is justified by adjusting risk weights to correctly reflect climate risks. We refer to such asset purchases as green quantitative easing (QE) in proposals below.

The climate risks in central banks' collateral frameworks and asset portfolios could be more adequately assessed and reflected. As discussed above, financial markets, including credit rating agencies, tend to underestimate climate risk, generating biases in capital allocation toward carbon-intensive activities. There is similar evidence of carbon intensity in the portfolios purchased in asset purchase programs (Matikainen et al. 2017, Battiston and 
Monasterolo 2019). Proposals have been made for central banks to correct this bias, notably by ceasing to rely primarily on market participants' risk assessments and developing own risk assessments. Ensuring that climate risks are appropriately reflected in central bank asset portfolios is fully within current mandates of central banks. In fact, it is against mandates not to reflect risks appropriately. Monnin (2018) highlights three virtues of such a shift. It would be consistent with sound monetary policy implementation and conservative risk assessment. It would mitigate central banks' exposure to climate risks. And it would help reduce the relative market value of carbon-intensive assets, which would increase incentives for investors to shift capital to low-carbon sectors. An added benefit would be to signal to financial actors the importance of incorporating climate risks into their asset valuation practices (NGFS 2019).

Beyond correcting risk weights, quantitative easing (QE) could be used to actively boost green asset prices (green QE). There have been calls to recalibrate asset purchase programs to outright exclude carbon-intensive assets and favor low-carbon assets (Ryan-Collins et al. 2013, Anderson 2015, van Lerven and Ryan-Collins 2017, Olovsson 2018), or to implement parallel asset purchase programs focused on low-carbon assets. ${ }^{27}$

\section{Proposals have also been made for central banks to structurally reallocate financial} resources toward green economic activities. Other proposals recommend steering the allocation of assets and collateral toward low-carbon sectors. For example, it has been suggested that central banks could use their balance sheets to provide guarantees to boost the financing of the huge investments needed to modify national production structures and gear them toward the low-carbon economy (Dasgupta et al. 2019). Similarly, central banks could ensure better access to funding schemes for commercial banks that invest in low-carbon projects (Aglietta et al. 2015) or purchase low-carbon bonds issued by national or multilateral development banks (De Grauwe 2019). Related proposals include amending forward guidance policies to raise market expectations regarding green investments (Campiglio 2016). For example, the PBoC uses a "window guidance" framework for the Chinese banking system to ensure that the allocation of credit across sectors follows the central bank's strategic plans, which focus on low-carbon sectors. All these proposals have the effect of lowering the relative cost of capital for low-carbon sectors (Schoenmaker 2019). See also Tooze (2019), Campiglio et al. (2018), Matikainen et al. (2017), and Battiston and Monasterolo (2019).

The use of central bank balance sheets to further low-carbon economic activity, beyond accounting appropriately for climate risks, raises important questions of governance. Such proposals go beyond current typical central bank mandates in advanced economies and many developing economies, are highly politically controversial and would require a rethink of the role of central banks. Central bankers are not elected officials, but act based on

${ }^{27}$ Green bond markets are small, but, as noted by Campiglio et al. (2018), growing rapidly. Their size was recently estimated at $€ 221$ billion (Climate Bond Initiative 2018). 
mandates from elected officials. Adding distributive policy risks unduly politicizing the central bank, thereby undermining its independence. More practically, adding goals while not adding tools dilutes the central bank's power to meet its goals and creates policy trade-offs (Tucker 2018). ${ }^{28}$ Further, the central bank may pay a price in terms of lower returns on its portfolio. Moreover, proposals that imply credit allocation or distribution might have an impact on the general government consolidated budget that would be similar to a fiscal package of carbon taxes and subsidies changing the same relative prices. ${ }^{29}$ These issues raise the question of the role of the central bank, and require further consideration.

There are other potential problems regarding the use of green QE. First, some central banks - such as the U.S. Federal Reserve - are restricted by law to the purchase of government bonds or government agency debt (Rudebusch 2019). These restrictions have been tightened further since the financial crisis. Nonetheless, the Federal Reserve's collateral framework includes a much broader array of assets than the list of assets eligible for outright purchases (Federal Reserve System 2018), potentially providing a case for integrating climate risk into credit risk assessments for the Fed's own operations. Second, QE has been designed to be temporary and aimed at price stability, and is therefore calibrated to affect output and inflation through bond purchases from a wide range of sectors that do not distort relative asset prices (Mersch 2018). ${ }^{30}$ Many low-carbon assets do not meet financial risk standards for central bank purchase eligibility, raising concerns over the impact of green asset purchases on central bank portfolios. Restricting asset purchases to low-carbon assets may restrict the eligible asset universe, reducing the effectiveness of QE when monetary policy is otherwise restricted by the zero lower bound. A further potential complication is that its contributions to the climate may come only during economic downturns at the zero lower bound, whereas arguably the impact would be stronger during upturns when investment activity is stronger. However, persistent low inflation and policy interest rates, very low inflation expectations in Europe and Japan and prolonged asset purchases by the ECB and the Bank of Japan raise the question of whether large central bank balance sheets may persist in some countries. Finally, enlisting monetary policy to support environmental policies may generate regulatory capture and rent-seeking behavior (Fay et al. 2015).

Elected officials can also decide on and implement active green asset purchases. The central bank balance sheet is not the only way to implement such policies. Similarly to sovereign wealth funds, a public fund could be set up that is independent of, but could perhaps be backstopped by, the central bank, subject to some of the same considerations

\footnotetext{
${ }^{28}$ It is also not clear whether central banks have the expertise needed to analyze climate-related issues, although arguably central banks could develop this expertise and/or acquire it through hiring.

${ }^{29}$ Goodfriend (2014) shows that any central bank balance sheet transaction amounting to redistributing credit across sectors is equivalent in budgetary terms to a set of taxes and subsidies.

${ }^{30}$ In the case of the European Central Bank, they also should not increase cross-country differences in the transmission of monetary policy (Weidmann 2017)
} 
about governance discussed above. A public fund could issue long-term safe liabilities and invest in assets financing low-carbon $\mathrm{R} \& \mathrm{D}$, green productive capacity and infrastructure. Such a fund is clearly in the gray zone between monetary and fiscal policy depending on how it is structured, and more analysis would be needed of the advantages relative to using more traditional fiscal instruments (see also the previous Section on fiscal policy). A variant of such a proposal is Aglietta and Coudert (2019), who propose creating trust funds in which unused SDRs in a reformed international monetary system could be invested to finance a guaranteed low-carbon investment program (Bredenkamp and Pattillo 2010 consider a similar proposal).

Some suggest that the magnitude of transition risks from climate change requires a change in monetary policy frameworks to support the transition. Due to increasing climate-related risks, financial stability may become closely connected to climate risk. Greater financial stability risks may lead to a higher weight on financial stability in central bank objectives and mandates. Aglietta et al. (2018) argue that this could necessitate the integration of macroprudential and monetary policies into a unified macrofinancial stability framework. McKibbin et al. (2017) argue that inflation targeting may no longer be effective in a carbon-constrained, climate-disrupted world. They argue that central banks need to respond to simultaneous increases in inflation and decreases in output as a result of climate policy, and climate disruptions will increase the frequency and severity of negative supply shocks. To avoid climate policy and monetary policy regimes working at cross-purposes, the authors argue that the two should be chosen jointly. Such proposals remain speculative but could become relevant as climate change proceeds.

\section{Other Policies for Climate Change Mitigation}

We have reviewed the literature on macroeconomic and financial policies, and thereby left out a multitude of other types of policies that could play a role. We briefly touch on some of these here for the sake of completeness.

Regulatory emissions standards could act as implicit carbon prices. These could complement explicit carbon prices and make it possible, especially for developing countries, to implement lower explicit carbon prices (Lecuyer and Quirion 2013). Regulations could focus on the efficiency of stocks of assets rather than their use, to help increase the efficiency of urban, transportation and infrastructure systems (Grubb et al. 2014).

Industrial policy could drive low-carbon technological change, although the risks associated with these policies must be carefully considered. Historical evidence suggests that the public sector can provide an impetus for the low-carbon technological transition, as occurred in the biotech and ICT industries. In those industries, public finance played a critical role through a network of decentralized public actors that supplied long-term capital for high-risk innovation (Mazzucato 2013b). There is evidence that a combination of a variety of policies (including building codes, land use and technology policies) can result in significant emissions abatement while enabling a significantly lower carbon price (Shukla et 
al. 2015). A recent example of an industrial policy to overcome coordination failures is the European Union's initiative on electricity storage and batteries (European Commission 2019). At the same time, there are clear risks in industrial policy, such as selecting the right industries to promote, and the risk of rent seeking and commercial interests unduly influencing this selection process (Rodrik 2019).

\section{Development banks could play an important role in financing the low-carbon} transition. Some see development banks as important actors in the financing of the lowcarbon transition, with many national and multilateral development banks having already introduced targeted lending programs (including the German KfW, the China Development Bank, the UK Green Investment Bank, and the World Bank's Global Infrastructure Facility) (Campiglio 2016). While development banks are constrained by the fact that, contrary to commercial banks, they cannot autonomously expand their balance sheets, coordination among different agencies could generate considerable financial resources for mitigation action, which could be amplified by crowding in institutional investors (Aglietta et al. 2016).

Proposals have been made to reform national accounting frameworks to generalize the definition of capital to intangible and environmental assets. This would give value not only to physical capital, but also to human capital and natural capital. One avenue is the Inclusive Wealth Index proposed in the Inclusive Wealth Report (UNEP 2018b). This framework could allow for defining sustainable development as a country's Inclusive Wealth Index (the sum of its physical, human and natural capital) not decreasing from one generation to the next.

Trade policy could in principle reduce carbon leakage. Border carbon adjustments (BCAs) may help accelerate mitigation through lower emissions leakage. However, they raise several potential issues, including the potentially contentious nature of measured embodied carbon in traded goods, retaliation and protectionism risks stemming from BCA use, and other complications under the Paris Agreement-non-price mitigation policies may need to be converted into carbon price equivalents, and determining the appropriate BCA penalty on countries whose mitigation pledges imply very different implicit carbon prices (IMF 2019a). Another proposal is to incorporate climate policy into the World Trade Organization framework by linking trade openness to adherence to the Paris Agreement and emissions reduction targets (see, e.g., Stone 2018). Regional trade agreements on climate have also been proposed. Climate clubs (agreements between groups of countries to introduce harmonized emissions reduction efforts and sanction nonparticipants through low and uniform tariffs on exports to countries in the club) have been suggested by Nordhaus (2015). See also Krogstrup and Obstfeld (2018).

Other policy areas include transparency, education and training, antitrust, as well as land use and conservation programs and labeling policies aimed at behavioral changes. For example, the emergence of low-carbon assets may require the development of an industry of independent experts capable of certifying the low-carbon nature of investment 
projects, while transparency and consumer education could help households reduce waste and improve the energy efficiency of their travel, housing and durable goods consumption.

\section{POLICY Mix, Framework, ANd COORDination}

The literature highlights the importance of coordinating policies in order to achieve the desired transition effectively and efficiently using available policy tools. Macroeconomic

and financial policy instruments can overlap in their incidence on climate mitigation and may also interact with other climate policies. The literature highlights the need for coordination between policies and policy areas to ensure effectiveness and efficiency of the policy mix (e.g., Sachs et al. 2014, Fay et al. 2015, High-Level Commission on Carbon Prices 2017). This is consistent with recent developments in the macroeconomic policy literature. For example, Bernanke (2019) argues that the general principle of central bank independence does not preclude coordination of central bank policies with other parts of the government in certain situations, and that periods of monetary-fiscal coordination may be essential for achieving key policy goals. An example of an avenue for enhancing coordination across policy areas is France's recent introduction of a High Climate Council tasked with evaluating the efficiency and coherence of public policies, carbon budgets, and the national strategy to 2050 .

The need for policy coordination is magnified by the unprecedented nature and scale of the climate challenge. Rodrik and Sabel (2019) argue that uncertainty about behavior, technology and the effectiveness of different policies implies that desirable policies span multiple margins of intervention and multiple policy instruments. In such conditions, the relevant policy space for addressing the challenge is of higher dimensionality and much more complex. ${ }^{31}$ Similarly, Engle et al. (2018) find that the existence of multiple market failures justifies several policy instruments, as in the case of climate change.

The literature is scarce on frameworks for discussing the most effective policy mix of these tools, however. The question of the desirable mix of policies for effective and efficient climate change mitigation remains relatively unexplored in the literature. A framework is proposed in Grubb et al. (2014). This framework rests on three pillars: regulation and engagement; markets and prices; and strategic investment. These pillars correspond to three climate policy approaches (energy efficiency, carbon pricing, and technology policy, respectively) and draw on three areas of economics. The first pillar draws on the insights of behavioral economics and focuses on energy standards and policies to drive better energy choices by consumers. The second draws on neoclassical economics and focuses on measures that affect absolute and relative energy prices. The third draws on institutional and evolutionary economics and focuses on long-term strategic investment. The three pillars are based on satisficing (the tendency of individuals and organizations to take decisions based on

\footnotetext{
${ }^{31}$ For example, Weitzman (1974) shows that quantity restrictions (i.e., hard regulation) may dominate price instruments in a dynamic environment with high uncertainty.
} 
habits and routines), optimizing (decisions aimed at optimal choices based on economic factors), and transforming (shaping complex systems through the strategic choices made by governments and large firms), respectively. Each pillar involves different actors, timescales, processes and instruments. A limitation of this framework, however, is that it does not explicitly discuss the role of finance and financial and monetary policies in transforming the structure of the economy to address the threat posed by climate change. It would be difficult to adapt to the concrete tool set considered here.

Some specific observations on the policy mix can be made based on our review of policies. First, we find that key fiscal, financial and monetary tools can work as complements to achieve the necessary behavioral change through both goods and asset price changes. Both public and private investments will be necessary in the transition, and both types of investments may be underprovided in the absence of specific fiscal and financial policies to achieve these, due to market and government failures. Even if fiscal policy were designed to address climate change mitigation, there would still be a role to play for financial policies to address financial market failures that can lead to underinvestment in green private productive capacity, infrastructure and $R \& D$. Correctly reflecting climate risks in financial institutions and central bank balance sheets would be part of such complementary tools.

\section{Whether more active financial and monetary instruments for climate change mitigation are substitutes or complements to fiscal tools is important for the assignment of policies.} This raises important and long-standing questions about which government authority should decide policies with redistributive impact, and more broadly, the role, mandate and independence of financial and monetary authorities. While monetary policy tools that shift asset prices toward green assets and credit can be effective in shifting incentives toward lowcarbon investments, there are questions as to the efficiency and appropriateness of such an approach. One view is that it may be a suboptimal substitute for more efficient fiscal instruments that can achieve the same, with more legitimacy than what can be achieved by financial and monetary authorities. This view implies that fiscal policy in terms of taxes and subsidies can achieve the same relative price changes as monetary policy tools that reallocate toward green investments and at the same cost to the consolidated budget constraint (Goodfriend 2014, Sargent and Wallace 1981).

Specific fiscal policy instruments can be constrained by government failures, as well as by social acceptability issues and powerful vested interest, as discussed in the next Section. Political impediments to carbon pricing may prove insurmountable, which in and of itself may warrant other macroeconomic or financial instruments that may be less efficient from a first-best perspective, but afford first-order impacts on energy prices (IMF 2019a). The implication is that the policy mix for implementing mitigation may end up being decided based on political or social feasibility rather than conceptual considerations, as the urgency of climate change mitigation may come to trump efficiency and institutional mandate considerations. 
Incorporating climate change mitigation into economic policy may require the development of a new policy framework. Given the existential threat of climate change, the toolbox and policy framework to address climate change will need to be further developed. The review of the literature presented in this paper points to two key types of intermediate policy goals to mitigate climate change: (i) policies to change the relative price of low-carbon goods, services, and assets; and (ii) policies to generate a sufficient increase in low-carbon investments (fiscal and financial policies, with monetary policy likely playing a supporting role). Key research questions center on how to select the policy mix to achieve effective and efficient climate mitigation, as well as how to coordinate this set of policies and the policy mix addressing climate change with policies addressing other goals, such as business cycle stabilization and price stability.

\section{Political Economy Considerations}

Political economy dimensions are critical to successful climate change mitigation. The low-carbon transition implies the replacement of entire sectors, economic activities and technologies, which in turn implies negative impacts for a wide range of economic actors and various groups (Fay et al. 2015). Carbon pricing is likely to result in higher energy prices, with potentially large negative effects on consumers in their access to relatively clean and modern energy, for example for cooking (generating potentially large health issues). The technology is available to transition to a low-carbon economy, and the case for doing so has long been clear. Policy instruments are also available. Yet, we are still on a path of increasing carbon emissions. This calls for more research on, and analysis of, political economy and global governance aspects of climate change mitigation.

Climate change mitigation can generate inequality within and between countries. Within countries, energy subsidy reform poses deep social and political acceptability issues, as exemplified by historical experience, notably in the Middle East, and, recently, the 'yellow vest' protests in France. This underlines the need for energy subsidy reforms to include spending or redistribution components. Energy subsidy reforms in the Middle East and North Africa that included compensatory measures for energy price hikes were associated with a successful outcome (Sdralevich et al. 2014). Similar patterns were observed in British Columbia (Jaccard 2012, Harrison 2013). In sum, the literature suggests that political viability reasons may justify the use of certain policy instruments (IMF 2019a).

\section{More generally, political economy considerations are central to successful climate policy packages. Studies argue that climate policy packages must be attractive to a majority of voters and avoid impacts that are perceived as unfair or are concentrated on a region, sector or group (see Fay et al. 2015). In the perspective of collective action problems, compensation of losers from climate policy may be needed on political economy grounds, as climate policy gains are intangible and unclear while climate policy costs are visible and concentrated on selected industries - making it difficult to create a vocal group of policy supporters (Olson 1977).}


This suggests that country circumstances matter for climate policies, notably due to the incidence of carbon pricing on households and firms. Carbon pricing may be regressive or progressive, depending on how it is designed, implying that political circumstances and the reuse of the proceeds of carbon taxes are key (IMF 2019a). Reuse of carbon tax proceeds can enable the reduction of other distorting taxes, low-carbon public investments, or lump-sum redistribution (although the progressive nature of the latter option has been questioned).

Climate change also affects between-country inequality. There is evidence that climate change has increased between-country income inequality, with per capita GDP being 17-31 percent lower for the poorest four deciles of the population-weighted country-level per capita GDP distribution, implying a ratio between the top and bottom deciles that is 25 percent larger than in a counterfactual scenario without global warming (Diffenbaugh and Burke 2019).

Climate change mitigation raises difficult problems of international policy coordination. First, climate change creates a free rider problem among countries, as climate benefits accrue mostly to other countries (IMF 2019a, Krogstrup and Obstfeld 2018). Second, lack of international cooperation and coordination can also incentivize countries to free ride on uneven emissions controls to gain competitive advantage. Third, climate change raises the question of who should contribute to the financing of mitigation action from a normative or moral perspective, and how much should each actor contribute (Bénassy-Quéré et al. 2018). One solution that has been proposed to address the issue of inadequate provisioning of public goods is a collective agreement on social value. This would enable the implementation and calibration of economic policies aimed at closing the gap between the production of goods and services with positive and negative externalities and what is socially desirable. Such an approach would be complementary to, but would go beyond, market relationships and could therefore be used to capture the interactions between the economy and the environment (Aglietta, ed., forthcoming). It would not solve the problems of countries' sense of entitlement based on historical emissions profiles of countries. Climate clubs, as mentioned in the previous section, could help limit free riding behavior by countries regionally.

Climate mitigation policies could increase growth and development, and reduce poverty, if well designed and implemented. Mitigation actions entail co-benefits as well as upfront costs and negative side effects (IPCC 2014). If the co-benefits are maximized through targeted policy, the transition to a low-carbon economy could enable sustainable and inclusive growth, characterized by a high rate of innovation, more livable cities, robust agriculture, and stronger ecosystems. Moreover, unilaterally embarking on climate change mitigation despite the free-rider disincentives can create a future competitive advantage for that country, thereby partly internalizing the global "leakage" of the benefits of unilateral mitigation policies. In short, carefully-designed climate policies are essential for getting the most out of the co-benefits and achieving the best possible transition (High-Level Commission on Carbon Prices 2017). 


\section{CONCLUSIONS}

The stakes of climate change mitigation are existential. The scientific consensus is that climate change is undermining the ecological systems on which human and all other forms of life depend. There is hence a need for climate change mitigation action to preserve the conditions not only for economic growth but for life within earth systems.

Climate change mitigation requires a transition in the structure of economic activity on a massive scale. There is an equally strong consensus within the scientific community that limiting global warming to well below $2^{\circ} \mathrm{C}$ requires a deep and rapid transformation in the structure of economic activity and therefore in the productive structure of the global economy, which in turn requires far-reaching transitions in the land, urban, industrial and infrastructure systems on which economic activity relies. The transition will require changes in relative prices of energy as well as increased investments in green infrastructure, productive capacity and $R \& D$.

On their own, markets cannot adequately address the challenge of climate change mitigation. Market failures are at the root of climate change and prevent an appropriate market response. Government failures amplify this problem. Some market failures can prevent sufficient long-term private investment even if public investments were sufficient and relative energy prices appropriate.

A wide range of macroeconomic and financial policy instruments can affect climate change and should be part of the policy effort toward mitigation. There is a broad menu of policy options from which policymakers can choose. Fiscal policy tools have been most emphasized in the literature, with the main options revolving around carbon pricing (explicit and implicit), spending and investment, and public guarantees. Financial policies can also have a key role to play in financing the low-carbon transition, with policies related to better reflecting and pricing climate risks in financial balance sheets, financial stability frameworks, and supporting climate-related financial market development and reforms. Monetary policy tools may also have a role to play. Options include better reflecting climate risks in the portfolios of large-scale asset purchase programs or collateral frameworks, which are within current central bank mandates. More controversial proposals include financial regulation that explicitly favors green investments, central bank credit allocation operations, and adapting monetary policy frameworks. Other policies (technology policies, regulatory standards) could also play a role.

\section{Financial and monetary policy tools can be divided into climate risk-focused and} climate finance-promoting policies. The former aim to correct the current lack of accounting for climate risks for individual financial institutions, whereas the latter aim to internalize externalities and co-benefits at the level of society. The first set of policies supports mitigation by changing the demand for green and carbon-intensive investments, as well as relative prices. The second set of policies can be effective in shifting relative prices 
and inducing investments, but gives rise to trade-offs and political economy considerations that require more attention in the literature.

Determining the most effective policy mix for climate change mitigation is an important next step. The literature highlights the potential importance of coordination among these policy areas, making the appropriate policy mix for successful climate change mitigation a pressing research topic. Some initial insights can be gleaned from the review. The literature provides a rationale for using some fiscal, financial and monetary instruments complementarily for mitigation purposes, notably to change relative prices and deliver the necessary productive public and private investments. Financial and monetary tools that go beyond accounting appropriately for climate risks may be substitutes for fiscal instruments, raising the need for more research to understand interactions and their potential role.

\section{A key message of this paper is the urgency of designing a mitigation-aligned} macroeconomic policy framework. Adding climate change mitigation as a goal in macroeconomic policy gives rise to questions about policy assignment and interactions with other policy goals such as financial stability, business cycle stabilization, and price stability. Political economy considerations complicate these questions. The literature does not provide answers yet. 


\section{APPENDIX: INTEGRATED ASSESSMENT MODELS}

This Appendix contains a brief discussion of Integrated Assessment Models.

\section{Integrated Assessment Models (IAMs) have been found to suffer from severe} limitations, suggesting that they do not provide accurate quantitative insights on climate damages. There are at least two types of IAMs: cost-benefit IAMs and processdriven IAMs. The latter explicitly represent the drivers and processes of change in global energy and land use systems linked to the broader economy (Guivarch and Pottier 2017). These IAMs do not represent damage from climate change. They are used to analyze pathways to achieve a pre-determined level of climate stabilization (such as $2^{\circ} \mathrm{C}$ ) in a costeffectiveness framework. Process-based IAMs include models used to quantify shared socioeconomic pathways (IPCC 2018). By contrast, the cost-benefit IAM approach aims to integrate climate issues into the Solow growth model (Solow 1956), with the Dynamic Integrated Climate-Economy (DICE) model (see Nordhaus 2014) having become a benchmark for IAMs. The literature suggests that IAMs suffer from limitations that cast doubt on the accuracy of the climate damage estimates they generate. A central argument is that there is insufficient scientific and empirical knowledge on the core elements of IAMs. Indeed, measures of the price of carbon that equate it to the marginal damages caused by the emission of an additional ton of carbon, which are at the center of standard cost-benefit analyses, suffer from the substantial uncertainty that surrounds these values (Pindyck 2013, 2017). Low cost estimates often reflect a focus on select components that are more easily quantifiable (Grubb et al. 2014), leaving many dimensions of the cost out. Furthermore, IAMs tend to use assumptions that are most favorable to growth (Moyer et al. 2014), and the functional form for the damage function is typically not based on theory or empirical foundations (Batten 2018). Assumptions that are less favorable to growth result in drastically greater impacts on growth (Dietz and Stern 2015). Curran et al. (2019) emphasize three flaws with cost-benefit IAMs: their lack of incorporation of many of the largest risks (in particular relating to climate thresholds, otherwise known as tipping points); their lack of account for the dynamic benefits of innovation, learning and feedback loops that promote institutional and behavioral change, discovery and economies of scale; and the high discount rates that they apply to future scenarios. A review of the literature on IAMs concludes that they can help provide qualitative indications on how complex systems behave but cannot be used to provide accurate quantitative insights, implying that climate action should be based on aversion to risk and the need to avoid a small but positive risk of a disastrous outcome (Heal 2017).

\section{Empirical analyses point to significant issues in IAMs' ability to account for interdependencies between economic activity and natural systems. Recent modeling work by the French Development Agency shows that damage functions applied to a hypothetical "global cooling" of $-4^{\circ} \mathrm{C}$ by 2100 (rather than the global warming that is normally used in analyses) yield limited damages that are inconsistent with the implications of such temperatures for the state of the earth. Indeed, such a global temperature anomaly}


would make most economic activity non-viable. A further issue affecting estimates of climate costs generated by IAMs is time discounting. Weighing the future benefits of climate action against the present costs requires valuing time and hence the present value of the welfare of future generations, but there are no objective criteria for making such an evaluation, which is inherently subjective and political (Grubb et al. 2014, Stern 2006, Weitzman 1998, 2010, 2011, Dasgupta 2008). Based on similar climate damage assessments, Cline (1992) and Nordhaus (1994) arrived at substantially different carbon reduction recommendations, reflecting different time discounting. Cline argued that the pure rate of time preference should be zero, since it is not ethical to weight future generations less than current generations. Nordhaus argued that the discount rate must be equal to the interest rate observed on financial markets, which at the time stood around 6 percent. ${ }^{32}$

${ }^{32}$ For a comparison of Stern's and Nordhaus' models, see Espagne (2018). 


\section{REFERENCES}

Acemoglu, D., P. Aghion, L. Bursztyn, and D. Hemous, 2012. "The Environment and Directed Technical Change," American Economic Review 102(1):131-66.

Addoum, J. M., D. Ng, and A. Ortiz-Bobea, forthcoming. "Temperature Shocks and Earnings News," Review of Financial Studies.

Admati, Anat R., 2017. "A Skeptical View of Financialized Corporate Governance," Journal of Economic Perspectives 31(3):131-50.

Adrian, T., F. Grinberg, N. Liang, and S. Malik, 2018. "The Term Structure of Growth-atRisk," IMF Working Paper No. 18/180, Washington, DC.

Aghion, P., R. Veugelers, and D. Hemous. 2009. "No Green Growth Without Innovation," Policy Briefs, Bruegel.

Aghion, P., A. Dechezleprêtre, D. Hemous, R. Martin, and J. van Reenen, 2015. "Carbon Taxes, Path Dependency and Directed Technical Change: Evidence from the Auto Industry." Journal of Political Economy 124(1):1-51.

Aglietta, M., E. Espagne, and B. Perrissin Fabert, 2015. "A proposal to finance low-carbon investment in Europe,” La Note D’Analyse No. 4, France Stratégie, Paris.

Aglietta, M., and E. Espagne, 2016. "Climate and Finance Systemic Risks, More Than an Analogy? The Climate Fragility Hypothesis," CEPII Working Paper no. 2016-10.

Aglietta, M., E. Espagne, and B. Perrissin Fabert, 2016. "Finance climat : le temps de l'action. Sept propositions pour la France et l'Europe,’ Terra Nova, December.

Aglietta, M., L. Arrondel, T. Brand, L. De Fossé, G. Dufrénot, R. Du Tertre, E. Espagne, A. Faivre, Y. Guy, A. Masson, A. Mayerowitz, W. Oman, and A. Pottier, 2018. "Transformer le régime de croissance," Rapport Institut CDC pour la Recherche, Paris.

Aglietta, M., and V. Coudert, 2019. "The Dollar and the Transition to Sustainable Development: From Key Currency to Multilateralism," CEPII Policy Brief 26, May.

Aglietta, M., ed., forthcoming. Capitalisme : le temps des ruptures, Odile Jacob, Paris.

Akerlof, G. A., 1970. “The Market for 'Lemons': Quality Uncertainty and the Market Mechanism," The Quarterly Journal of Economics 84(3):488-500.

Anderson, V., 2015. Green Money: Reclaiming Quantitative Easing Money Creation for the Common Good, Green/EFA Group in the European Parliament.

Andersson, M., P. Bolton, and F. Samama, 2016. "Hedging Climate Risk," Financial Analysts Journal 72(3):1-20. 
Arezki, R., and M. Obstfeld, 2015. "The Price of Oil and the Price of Carbon," VoxEU, https://voxeu.org/article/price-oil-and-price-carbon.

Arezki, R., F. Samama, J. Stiglitz, P. Bolton, and S. Peters, 2016. "From Global Savings Glut to Financing Infrastructure: The Advent of Investment Platforms," IMF Working Paper No. 16/18, Washington, DC.

Arezki, R., and F. Belhaj, 2019. "Developing Public-Private Partnership Initiatives in the Middle East and North Africa," Policy Research Working Paper No. 8863, World Bank, Washington, DC.

Auffhammer, M., 2018. "Quantifying Economic Damages from Climate Change," Journal of Economic Perspectives 32(4):33-52.

Ball, L., J. Gagnon, P. Honohan, and S. Krogstrup, 2016. "What Else Can Central Banks Do?" Geneva Reports on the World Economy 18, International Center for Monetary and Banking Studies, Geneva.

Banco Central do Brasil, 2011. Circular 3, 547 of July 7, 2011: Establishes Procedures and Parameters Related to the Internal Capital Adequacy Assessment Process (ICAAP), http://www.bcb.gov.br/ingles/norms/brprudential/Circular3547.pdf.

Bank of England, 2019a. "Enhancing banks' and insurers' approaches to managing the financial risks from climate change," Supervisory Statement SS3/19, April.

Bank of England, 2019b. "Insurance Stress Test 2019," June 18. Retrieved from: https://www.bankofengland.co.uk/prudential-regulation/letter/2019/insurance-stress-test$\underline{2019}$

Bank of England, 2019c. "New economy, new finance, new Bank: The Bank of England's response to the van Steenis review on the Future of Finance," Bank of England Report, June.

Bank of England, 2019d. "Bank of England to disclose assessment of how it manages climate-related financial risk in the 2019/20 annual report," Bank of England News Release, April.

Banque du Liban, 2010. Intermediate Circular 236.

Bathiany, S., V. Dakos, M. Scheffer, and T. M. Lenton, 2018. "Climate Models Predict Increasing Temperature Variability in Poor Countries," Science Advances 4(5):EAAR5809.

Batini, N., 2019. "Macroeconomic Gains from Reforming the Agri-Food Sector: The Case of France," IMF Working Paper No. 19/41, Washington, DC.

Batten, S., 2018. "Climate Change and the Macro-Economy: A Critical Review," Bank of England Staff Working Paper No. 706. 
Batten, S., R. Sowerbutts, and M. Tanaka, 2016. "Let's Talk About the Weather: The Impact of Climate Change on Central Banks," Bank of England Staff Working Paper No. 603.

Battiston, S., 2019. "The importance of being forward-looking: managing financial stability in the face of climate risk," in Greening the financial system: the new frontier, Banque de France Financial Stability Review, June 2019.

Battiston, S., A. Mandel, I. Monasterolo, F. Schütze, and G. Visentin, 2017. "A climate stress-test of the financial system," Nature Climate Change 7:283-288.

Battiston, S., and I. Monasterolo, 2019. "How could the ECB's monetary policy support the sustainable finance transition?" mimeo, University of Zurich.

BCBS, 2016. Guidance on the application of the core principles for effective banking supervision to the regulation and supervision of institutions relevant to financial inclusion, Basel Committee on Banking Supervision, September.

Bénassy-Quéré, A., B. Cœuré, P. Jacquet, and J. Pisani-Ferry, 2018. Economic Policy: Theory and Practice, New York, Oxford University Press.

Bernanke, B. S., 2019. "Monetary Policy in a New Era," in Evolution or Revolution: Rethinking Macroeconomic Policy After the Great Recession, O. Blanchard and L. H. Summers (eds.), Cambridge, The MIT Press.

Bhattacharya, A., J. Oppenheim, and N. H. Stern, 2015. "Driving sustainable development through better infrastructure: key elements of a transformation program," Brookings Global Working Paper Series.

BlackRock Investment Institute, 2015. The price of climate change: Global warming's impact on portfolios. Retrieved from: https://www.blackrock.com/corporate/en$\underline{\mathrm{mx} / \text { literature/whitepaper/bii-pricing-climate-risk-international.pdf }}$

Blanchard, O. J., 2019. "Public Debt: Fiscal and Welfare Costs in a Time of Low Interest Rates," Policy Briefs PB19-2, Peterson Institute for International Economics, Washington, DC.

Bramoullé, Y., and L. J. Olson, 2005. "Allocation of pollution abatement under learning by doing," Journal of Public Economics 89(9):1935-1960.

Bredenkamp, H., and C. A. Pattillo, 2010. "Financing the Response to Climate Change," IMF Staff Position Note SPN10/06, Washington, DC.

Brunner, S., C. Flachsland, and R. Marschinski, 2012. "Credible commitment in carbon policy," Climate Policy, 12:255-271. 
Burke M., S. M. Hsiang, and E. Miguel, 2015. "Global Non-linear Effect of Temperature on Economic Production," Nature 527:235-39.

Campiglio, E., 2016. "Beyond carbon pricing: The role of banking and monetary policy in financing the transition to a low-carbon economy," Ecological Economics 121:220-230.

Campiglio, E., Y. Dafermos, P. Monnin, J. Ryan-Collins, G. Schotten, and M. Tanaka, 2018. "Climate change challenges for central banks and financial regulators," Nature Climate Change 8:462-468.

Carbon Tracker, 2013. "Unburnable Carbon 2013: Wasted Capital and Stranded Assets," Technical Report.

Carney, M., 2015. "Breaking the tragedy of the horizon - climate change and financial Stability," Speech at Lloyd's of London, September 29.

Carney, M., 2019. “A New Horizon,” Speech at the European Commission Conference: A global approach to sustainable finance, Brussels, March 21.

Cerutti, E., S. Claessens, and L. Laeven, 2017. "The use and effectiveness of macroprudential policies: New evidence," Journal of Financial Stability 28:203-224.

Chang, H. J., 2006. "Industrial Policy in East Asia - Lessons for Europe," European Investment Bank, Economic and Financial Studies.

Chichilnisky G., and G. M. Heal, 1993. "Global Environmental Risks," Journal of Economic Perspectives 7(4):65-86.

Christophers, B., 2017. "Climate Change and Financial Instability: Risk Disclosure and the Problematics of Neoliberal Governance," Annals of the American Association of Geographers 107(5):1108-1127.

Climate Leadership Council, 2019. "Economists' Statement on Carbon Dividends," as appeared in the Wall Street Journal, January 17, 2019. Retrieved from: https://www.clcouncil.org/economists-statement/

Cline, W. R., 1992. The Economics of Global Warming, Institute for International Economics, Washington, DC.

Coady, D., I. Parry, N.-P. Le, and B. Shang, 2019. "Global Fossil Fuel Subsidies Remain Large: An Update Based on Country-Level Estimates," IMF Working Paper No. 19/89, Washington, DC.

Cœuré, B., 2018. "Monetary policy and climate change," Speech given at a conference on "Scaling up Green Finance: The Role of Central Banks," organized by the Network for 
Greening the Financial System, the Deutsche Bundesbank and the Council on Economic Policies, Berlin, November 8.

Colacito, R., B. Hoffmann, T. Phan, and T. Sablik, 2018. "The Impact of Higher Temperatures on Economic Growth," FRB Richmond Economic Brief EB18-08, August.

Curran, P., N. Robins, and N. H. Stern, 2019. "Unlocking the strategic economic opportunity of clean and inclusive growth," in Greening the financial system: the new frontier, Banque de France Financial Stability Review, June 2019.

Dasgupta, D., forthcoming. Climate Finance: Committing to the Planet's Future?

Dasgupta, D., J.-C. Hourcade, and S. Nafo, 2019. A Climate Finance Initiative.

Dasgupta, P., 2008. "Discounting climate change," Journal of Risk and Uncertainty, 37(23):141-169.

De Grauwe, P., 2019. “Green Money Without Inflation,” Council on Economic Policies

Blog, March 7. Retrieved from: https://www.cepweb.org/green-money-without-inflation/

De Laubier-Longuet Marx, N., E. Espagne, and T. Ngo-Duc, 2019. "Non-Linear Impacts of Climate Change on Income and Inequality in Vietnam," AFD Research Paper Series No. 2019-101.

Debelle, G., 2019. "Climate Change and the Economy," Speech at public forum hosted by Centre for Policy Development, Sydney, Australia, March 12.

Deryugina, T., and S. M. Hsiang, 2014. "Does the Environment Still Matter? Daily Temperature and Income in the United States," NBER Working Paper No. 20750.

Dietz S., and N. H. Stern, 2015. "Endogenous Growth, Convexity of Damage and Climate Risk: How Nordhaus' Framework Supports Deep Cuts in Carbon Emissions," Economic Journal 125(583):574-620.

Dietz, S., A. Bowen, C. Dixon, and P. Gradwell, 2016. "“Climate value at risk' of global financial assets," Nature Climate Change 6:676-679.

Diffenbaugh, N. S., and M. Burke, 2019. "Global warming has increased global economic inequality," Proceedings of the National Academy of Sciences of the United States of America.

Dikau, S., and U. Volz, 2019a. "Central Banking, Climate Change, and Green Finance," in Handbook of Green Finance, J. D. Sachs, W. T. Woo, N. Yoshino, and F. TaghizadehHesary (eds.), Singapore, Springer.

Dikau, S., and U. Volz, 2019b. "Central Bank Mandates, Sustainability Objectives and the 
Promotion of Green Finance," SOAS Department of Economics, Working Paper No. 222.

D'Orazio, P., and L. Popoyan, 2019. "Fostering green investments and tackling climaterelated financial risks: Which role for macroprudential policies?" Ecological Economics 160:25-37.

Drèze, J., and N. H. Stern, 1990. "Policy reform, shadow prices, and market prices," Journal of Public Economics 42(1):1-45.

Engle, N., C. Brandon, S. Hallegatte, P. Hannam, and D. Heine, 2018. "Strategic Use of Climate Finance to Maximize Climate Action: A Guiding Framework," World Bank, Washington, DC.

Espagne, E. 2018. "Money, Finance and Climate: The Elusive Quest for a Truly Integrated Assessment Model," Comparative Economic Studies 60(1):131-143.

ESRB, 2016. Too late, too sudden: Transition to a low-carbon economy and systemic risk, Reports of the Advisory Scientific Committee. No 6, European Systemic Risk Board.

European Commission, 2017. Reinforcing Integrated Supervision to Strengthen Capital Markets Union and Financial Integration in a Changing Environment.

European Commission, 2019. Report from the Commission to the European Parliament, The Council, The European Economic and Social Committee, the Committee of the Regions and the European Investment Bank on the Implementation of the Strategic Action Plan on Batteries: Building a Strategic Battery Value Chain in Europe.

EU High-Level Expert Group on Sustainable Finance, 2018. Financing a Sustainable European Economy, European Commission.

Farid, M., M. Keen, M. G. Papaioannou, I. W. H. Parry, C. A. Pattillo, A. Ter-Martirosyan, 2016. "After Paris: Fiscal, Macroeconomic, and Financial Implications of Climate Change," IMF Staff Discussion Note 16/01.

Fay, M., S. Hallegatte, A. Vogt-Schilb, J. Rozenberg, U. Narloch, and T. Kerr, 2015. Decarbonizing Development: Three Steps to a Zero-Carbon Future, World Bank Group, Washington, DC.

Federal Reserve System, 2018. Federal Reserve Collateral Guidelines, March.

Flaherty, M., A. Gevorkyan, S. Radpour, and W. Semmler, 2017. "Financing Climate Policies through Climate Bonds - A Three Stage Model and Empirics," Research in International Business and Finance 42:468-79.

Flammer, C., 2019. "Green Bonds: Effectiveness and Implications for Public Policy,” NBER Working Paper No. 25950. 
Gagnon, J., M. Raskin, J. Remache, and B. Sack, 2011. "The Financial Market Effects of the

Federal Reserve's Large-Scale Asset Purchases," International Journal of Central Banking $7(1): 3-43$.

Galati, G., and R. Moessner, 2017. "What do we know about the effects of macroprudential policy?” Economica 85(340):735-770.

García-Álvarez, M. T., L. Cabeza-García, and I. Soares, 2017. "Analysis of the promotion of onshore wind energy in the EU: Feed-in tariff or renewable portfolio standard?" Renewable Energy 111:256-264.

Goodfriend, M., 2014. "Lessons from a century of FED policy: Why monetary and credit policies need rules and boundaries," Journal of Economic Dynamics and Control 49:112120.

Goulder, L. H., 1995. "Environmental taxation and the double dividend: A reader's guide," International Tax and Public Finance 2:157-183.

Grubb, M., J.-C. Hourcade, and K. Neuhoff, 2014. Planetary Economics: Energy, Climate Change and the Three Domains of Sustainable Development, Routledge, New York.

Grubb, M., I. Bashmakov, P. Drummond, A. Myshak, N. Hughes, A. Biancardi, P. Agnolucci, and R. Lowe, 2018. "An Exploration of Energy Cost, Ranges, Limits and Adjustment Process," London, Final report to the Institute of New Economic Thinking.

Guillaume, D. M., R. Zytek, and M. Reza Farzin, 2011. "Iran: The Chronicles of the Subsidy Reform,” IMF Working Paper No. 11/167, Washington, DC.

Guivarch, C., and A. Pottier. "Climate Damage on Production or on Growth: What Impact on the Social Cost of Carbon?” Environmental Modeling \& Assessment 23(2):117-130.

Hallegatte, S., M. Fay, and A. Vogt-Schilb, 2013. "Green Industrial Policies: When and How,” Policy Research Working Paper 6677, World Bank, Washington, DC.

Harrison, K., 2013. "The Political Economy of British Columbia's Carbon Tax," OECD Environment Working Papers, no. 63, Organisation for Economic Co-operation and Development, Paris.

Haut Conseil pour le Climat, 2019. “Agir en cohérence avec les ambitions,” Rapport annuel Neutralité Carbone, Paris.

Hawkins, E., and R. Sutton, 2009. "The Potential to Narrow Uncertainty in Regional Climate Predictions," American Meteorological Society 90(8):1095-1107.

Heal, G., 2017. "The Economics of the Climate," Journal of Economic Literature 55(3):1046-63. 
Heine, D., and S. Black, 2019. "Benefits beyond Climate: Environmental Tax Reforms," in Fiscal Policies for Development and Climate Action, Pigato, M. (ed.), World Bank Group, Washington, DC.

Heine, D., W. Semmler, M. Flaherty, A. Gevorkyan, E. Hayde, M. Mazzucato, and S. Radpour, 2018. "Financing Low-Carbon Transitions through Carbon Pricing and Green Bonds," Vierteljahrshefte Zur Wirtschaftsforschung 88(1).

Helm, D., C. Hepburn, and R. Mash, 2003. "Credible Carbon Policy," Oxford Review of Economic Policy 19(3):438-450.

High-Level Commission on Carbon Prices, 2017. Report of the High-Level Commission on Carbon Prices, World Bank, Washington DC,.

Hong, H., F. Li, and J. Xu, 2019. “Climate risks and market efficiency,” Journal of Econometrics 208(1):265-281.

Hourcade, J.-C., P.-R. Shukla, and C. Cassen, 2015. "Climate policy architecture for the Cancun paradigm shift: building on the lessons from history," International Environmental Agreements: Politics, Law and Economics 15(4):353-367.

Hourcade, J.-C., A. Pottier, and E. Espagne, 2018. "Social Value of Mitigation Action and Forms of Carbon Pricing," International Economics 155:8-18.

Hsiang, S. M., 2019. "Statement of Solomon Hsiang to be presented to: United States House Committee on the Budget, hearing on 'The Costs of Climate Change: Risks to the U.S. Economy and the Federal Budget."' Retrieved from: https://www.solomonhsiang. com/s/Testimony Hsiang 6 10 10 19.pdf

Hsiang, S. M., R. Kopp, A. Jina, J. Rising, M. Delgado, S. Mohan, D. J. Rasmussen, et al., 2017. "Estimating economic damage from climate change in the United States," Science 356(6345):1362-1369.

Hsiang, S., and R. Kopp, 2018. “An Economist's Guide to Climate Change Science," Journal of Economic Perspectives 32(4):3-32.

IEA, 2017. "Renewable Energy for Industry_From Green Energy to Green Materials and Fuels,” IEA Insights Paper, International Energy Agency, Paris.

IEA, 2018. World Energy Outlook 2018, International Energy Agency, Paris.

IMF, 2017. "The Effects of Weather Shocks on Economic Activity," in World Economic Outlook, Chapter 3, International Monetary Fund, October. 
IMF, 2018. "Euro Area Policies: Financial System Stability Assessment: Detailed Assessment of Observance-Basel Core Principles for Effective Banking Supervision," International Monetary Fund, June.

IMF, 2019a. "Fiscal Policies for Paris Climate Strategies: From Principle to Practice," IMF Board Paper, International Monetary Fund, March.

IMF, 2019b. "The Rise of Corporate Market Power and Its Macroeconomic Effects," World Economic Outlook, Chapter 2, International Monetary Fund, April.

Innes, A., 2018. "First-Best-World Economic Theory and the Second-Best-World of Public Sector Outsourcing: The Reinvention of the Soviet Kombinat by Other Means," LSE 'Europe in Question' Discussion Paper Series (LEQS), London School of Economics.

Institute for Climate Economics, 2018. "Getting started on Physical climate risk analysis in finance - Available approaches and the way forward," ClimINVEST Research ProjectWork Package 1.

IPBES, 2019. "Summary for policymakers of the global assessment report on biodiversity and ecosystem services," Intergovernmental Science-Policy Platform on Biodiversity and Ecosystem, Germany.

IPCC, 2014. Climate change 2014 Synthesis Report, Intergovernmental Panel on Climate Change, Switzerland.

IPCC, 2018. Global Warming of $1.5^{\circ}$ C, Intergovernmental Panel on Climate Change, Switzerland.

Jaccard, M., 2012. "The political acceptability of carbon taxes: lessons from British Columbia," pp. 175-191 in Handbook of Research on Environmental Taxation, J. E. Milne, and M. S. Andersen (eds.), Edward Elgar, Cheltenham, UK, Northampton, MA.

Kapp, K. W., 1950. The Social Costs of Private Enterprise, Harvard University Press, Cambridge.

King, M. R., 2013. "The Basel III net stable funding ratio and bank net interest margins," Journal of Banking \& Finance 37(11):4144-4156.

Klenert, D., L. Mattauch, E. Combet, O. Edenhofer, C. Hepburn, R. Rafaty, and N. H. Stern, 2018. "Making carbon pricing work for citizens," Nature Climate Change 8:669-677.

Koedijk, K. G., P. Loungani, and P. Monnin, 2018. "Monetary policy, macroprudential regulation and inequality: An introduction to the special section," Journal of International Money and Finance 85:163-167. 
Krogstrup, S., and M. Obstfeld, 2018. “A Planet at Risk Requires Multilateral Action,” IMF Blog, December 3.

Lagarde, C., and V. Gaspar, 2019. “Getting Real on Meeting Paris Climate Change Commitments,” IMF Blog, May 3.

Lane, P., 2019. "Climate change and the Irish financial system," Presentation of economic letter to the 2019 Monsignor Pádraig de Brún Memorial Lecture, National University of Ireland Galway, Galway, February 5.

Lecuyer, O. and P. Quirion, 2013. "Can uncertainty justify overlapping policy instruments to mitigate emissions?” Ecological Economics 93:177-191.

Matikainen, S., E. Campiglio, and D. Zenghelis, 2017. "The Climate Impact of Quantitative Easing," Grantham Research Institute on Climate Change and the Environment.

Mazzucato, M., 2013a. "Financing innovation: creative destruction vs. destructive creation," Industrial and Corporate Change 22(4):851-867.

Mazzucato, M., 2013b. The Entrepreneurial State: Debunking Public vs. Private Sector Myths, Anthem Press, New York.

McGlade, C., and P. Ekins, 2015. "The geographical distribution of fossil fuels unused when limiting global warming to $2^{\circ} \mathrm{C}$," Nature 517:187-190.

McKibbin, W. J., A. C. Morris, P. J. Wilcoxen, and A. J. Panton, 2017. "Climate Change and Monetary Policy: Dealing with Disruption," Climate and Energy Economics Discussion Paper, Brookings, Washington DC.

Meinshausen, M., N. Meinhausen, W. Hare, S. C. B. Raper, K. Frieler, R. Knutti, D. J. Frame, M. R. Allen, 2009. "Greenhouse-gas emission targets for limiting global warming to $2^{\circ} \mathrm{C}$," Nature 458:1158-1162.

Mersch, Y., 2018. "Climate change and central banking," Speech at the Workshop discussion "Sustainability is becoming mainstream," Frankfurt am Main, November 27.

Monnin, P., 2018. "Central banks should reflect climate risks in monetary policy operations," SUERF Policy Note, Issue No 41.

Moyer E. J., M. D. Woolley, N. J. Matteson, M. J. Glotter, and D. A. Weisbach, 2014. "Climate impacts on economic growth as drivers of uncertainty in the social cost of carbon," Journal of Legal Studies 43(2):401-425.

Nelson, D., and G. Shrimali, 2014. "Finance Mechanisms for Lowering the Cost of Renewable Energy in Rapidly Developing Countries," Climate Policy Initiative. 
NGFS, 2018. First Progress Report, Network for Greening the Financial System, October.

NGFS, 2019. NGFS First comprehensive report-A call for action: Climate change as a source of financial risk, Network for Greening the Financial System, April.

Nordhaus, W. D., 1994. Managing the Global Commons: The Economics of Climate Change, The MIT Press, Cambridge.

Nordhaus, W. D., 2014. A Question of Balance: Weighing the Options on Global Warming Policies, Yale University Press, New Haven and London.

Nordhaus, W. D., 2015. "Climate Clubs: Overcoming Free-Riding in International Climate Policy,” American Economic Review 105(4):1339-1370.

OECD, 2017. Investing in Climate, Investing in Growth, Organisation for Economic Cooperation and Development, Paris.

Olovsson, C., 2018. “Is Climate Change Relevant for Central Banks?” Sveriges Riksbank Economic Commentaries 13, November.

Olson, M., 1977. The Logic of Collective Action: Public Goods and the Theory of Groups (Revised ed.), Harvard University Press, Cambridge.

Orlov, S., E. Rovenskaya, J. Puaschunder, and W. Semmler, 2018. "Green Bonds, Transition to a Low-Carbon Economy, and Intergenerational Fairness: Evidence from an Extended DICE Model," Laxenburg, International Institute for Applied Systems Analysis.

Parry, I., V. Chandara, and D. Heine, 2015. "How Much Carbon Pricing Is in Countries' Own Interests? The Critical Role of Co-Benefits," Climate Change Economics 06(04).

PBoC, 2018. China Monetary Policy Report-Quarter Four 2017, People's Bank of China.

Persaud, A., 2015. "How Not to Regulate Insurance Markets: The Risks and Dangers of Solvency II,” Policy Briefs PB15-5, Peterson Institute for International Economics, Washington, DC.

Persson, T., and G. Tabellini, 1999. "Political economics and macroeconomic policy," in Handbook of Macroeconomics, J. B. Taylor and M. Woodford (eds.), Elsevier.

Pigato, M., ed., 2019. Fiscal Policies for Development and Climate Action, World Bank Group, Washington, D.C.

Pigou, A., 1932. The Economics of Welfare, $4^{\text {th }}$ ed., London, Macmillan.

Pindyck, R. S., 2013. "Climate change policy: What do the models tell us?" Journal of Economic Literature 51(3):860-872. 
Pindyck, R. S., 2017. "The use and misuse of models for climate policy," Review of Environmental Economics and Policy 11(1):100-114.

Pottier, A., 2016. Comment les économistes réchauffent la planète, Le Seuil, Paris.

Prudential Regulation Authority, 2015. The Impact of Climate Change on the UK Insurance Sector.

Raworth, K., 2017. Doughnut Economics: Seven Ways to Think Like a 21st-Century Economist, Chelsea Green Publishing, Hartford.

Rey, H., 2019. “Environnement : La myopie coupable des investisseurs," Les Echos, April 11. Retrieved from: https://www.lesechos.fr/amp/1008448

Rigaud, K. K., A. de Sherbinin, B. Jones, J. Bergmann, V. Clement, K. Ober, J. Schewe, S. Adamo, B. McCusker, S. Heuser, and A. Migley, 2018. "Groundswell: Preparing for Internal Climate Migration," World Bank, Washington, DC.

Rockström, J., W. Steffen, K. Noone, Å. Persson, F. S. Chapin III, E. F. Lambin, T. M. Lenton, M. Scheffer, C. Folke, H . J. Schellnhuber, and B. Nykvist, 2009. "A safe operating space for humanity," Nature 461:472-475.

Rodrik, D., 2014. “Green Industrial Policies,” Oxford Review of Economic Policy 30(3):469491.

Rodrik, D., 2019. "Where are we in the economics of industrial policies?" VoxDev. Retrieved from: https://voxdev.org/topic/public-economics/where-are-we-economicsindustrial-policies

Rodrik, D., and C. Sabel, 2019. "Building a Good Jobs Economy,” mimeo, Harvard University.

Rogoff, K., 2019. “The Case for a World Carbon Bank," Project Syndicate, July 8. Retrieved from: https://www.project-syndicate.org/commentary/world-carbon-bank-for-developingcountries-by-kenneth-rogoff-2019-07

Rozenberg, J., A. Vogt-Schlib, and S. Hallegatte, 2014. "Transition to Clean Capital, Irreversible Investment and Stranded Assets," Policy Research Working Paper No. 6859, World Bank Group, Washington, DC.

Rudebusch, G., 2019. “Climate Change and the Federal Reserve," FRBSF Economic Letter 2019-09, March 25.

Ruggeri Laderchi, C. 2014. "Transitional Policies to Assist the Poor While Phasing out Inefficient Fossil Fuel Subsidies That Encourage Wasteful Consumption," Contribution by the World Bank to G20 Finance Ministers and Central Bank Governors. 
Ryan-Collins, J., R. Werner, T. Greenham, and G. Bernardo, 2013. "Strategic Quantitative Easing: Stimulating Investment to Rebalance the Economy," New Economics Foundation.

Sachs, J., 2015. "Climate Change and Intergenerational Well-Being," in Oxford Handbook of the Macroeconomics of Global Warming, L. Bernard and W. Semmler (eds.), Oxford University Press, Oxford.

Sachs, J., L. Tubiana, E. Guerin, H. Waisman, C. Mas, M. Colombier, and G. SchmidtTraub, 2014. Pathways to Deep Decarbonization: 2014 Report, Sustainable Development Solutions Network and Institute for Sustainable Development and International Relations.

Sargent, T. J., and N. Wallace, 1981. "Some Unpleasant Monetarist Arithmetic," Quarterly Review, Federal Reserve Bank of Minneapolis, issue Fall.

Schmidt, T., 2014. "Low-carbon investment risks and de-risking," Nature Climate Change (4):237-239.

Schneider, S., 1997. "Integrated assessment modeling of global climate change: Transparent rational tool for policy making or opaque screen hiding value-laden assumptions?"

Environmental Modeling \& Assessment 2(4):229-249.

Schoenmaker, D., 2019. “Greening Monetary Policy,” Bruegel Working Paper Issue 02.

Schoenmaker, D., and R. V. Tilburg, 2016. "What role for financial supervisors in addressing environmental risks?” Comparative Economic Studies 58:317-334.

Scott, M., J. van Huizen, and C. Jung, 2017. "The Bank of England's Response to Climate Change,” Bank of England Quarterly Bulletin, Q2, 98-109.

Sdralevich, C. A., R. Sab, Y. Zouhar, and G. Albertin, 2014. Subsidy Reform in the Middle East and North Africa: Recent Progress and Challenges Ahead, International Monetary Fund, Washington, DC.

Shleifer, A., and R. W. Vishny, 1990. "Equilibrium Short Horizons of Investors and Firms," American Economic Review Papers and Proceedings 80(2):148-153.

Shleifer, A., and R. W. Vishny, 1997. "The Limits of Arbitrage," Journal of Finance 52(1):35-55.

Shukla, P. R., S. Dhar, M. Pathak, D. Mahadevia, A. Garg, 2015. Pathways to Deep Decarbonization in India, SDSN - IDDRI.

Solow, R. M., 1956. "A Contribution to the Theory of Economic Growth," The Quarterly Journal of Economics 70(1):65-94. 
Solow, R. M., 1971. “The Economist's Approach to Pollution and Its Control," Science 173(3996):498-503.

Sowerbutts, R. 2016. "No smog without fire: The financial stability risks around carbonintensive investments," Bank of England. Retrieved from:

https://bankunderground.co.uk/2016/07/06/no-smog-withoutfire-the-financial-stability-risksaround-carbon-intensiveinvestments/

Spencer, T., and J. Stevenson, 2013. "EU Low-carbon Investment and New Financial Sector Regulation: What Impacts and What Policy Response," IDDRI, Sciences Po, Paris.

Steffen, W., J. Rockström, K. Richardson, T. M. Lenton, et.al., 2018. "Trajectories of the Earth System in the Anthropocene," Proceedings of the National Academy of Sciences of the United States of America 115(33):8252-8259.

Stern, N. H., 2006. Stern Review: The Economics of Climate Change, vol. 30, HM Treasury, London.

Stern, N. H., 2015. Why Are We Waiting? The Logic, Urgency, and Promise of Tackling Climate Change, The MIT Press, Cambridge.

Stern, N. H., 2016. "Economics: Current Climate Models Are Grossly Misleading," Nature 530(7591):407-409.

Stiglitz, J. E., and A. Weiss, 1981. "Credit Rationing in Markets with Imperfect Information," American Economic Review 71(3):393-410.

Stone, J., 2018. "EU to refuse to sign trade deals with countries that don't ratify Paris climate change accord," The Independent, 12 February. Retrieved from: https://www.independent.co.uk/news/world/europe/eu-trade-deal-paris-climate-changeaccord-agreement-cecilia-malmstr-m-a8206806.html

Svartzman, R., D. Dron, and E. Espagne, 2019. "From Ecological Macroeconomics to a Theory of Endogenous Money for a Finite Planet," Ecological Economics 162:108-120.

Thomä, J., and A. Hilke, 2018. "The Green Supporting Factor: Quantifying the Impact on European Banks and Green Finance," $2^{\circ}$ Investing Initiative, Berlin.

Tol, R. S. J., 2018. “The Economic Impacts of Climate Change," Review of Environmental Economics and Policy 12(1):4-25.

Tol, R. S. J., 2019. "A social cost of carbon for (almost) every country," Working Paper Series 02-2019, University of Sussex. 
Tooze, A., 2019. "Why Central Banks Need to Step Up on Global Warming," Foreign Policy, July. Retrieved from: https://foreignpolicy.com/2019/07/20/why-central-banks-needto-step-up-on-global-warming/

Tucker, P., 2018. Unelected Power: The Quest for Legitimacy in Central Banking and the Regulatory State, Princeton University Press, New York.

UNEP, 2018a. The Emissions Gap Report, United Nations Environment Program, Nairobi.

UNEP, 2018b. Inclusive Wealth Report 2018, United Nations Environment Program, Nairobi.

UNFCCC, 2016a. "Decisions adopted by the Conference of the Parties," United Nations Framework Convention on Climate Change, New York City. Available at: https://unfccc.int/resource/docs/2015/cop21/eng/10a01.pdf.

UNFCCC, 2016b. Paris Agreement, United Nations Framework Convention on Climate Change, New York City. Available at:

https://unfccc.int/sites/default/files/english paris agreement.pdf.

Unruh, G., 2000. “Understanding Carbon Lock-In,” Energy Policy 28(2000):817-30.

USGCRP, 2017. Climate Science Special Report: Fourth National Climate Assessment, Volume I, U.S. Global Change Research Program, Washington, DC.

USGCRP, 2018. Impacts, Risks, and Adaptation in the United States: Fourth National Climate Assessment, Volume II, U.S. Global Change Research Program, Washington, DC.

van Lerven, F., and J. Ryan-Collins, 2017. "Central Banks, Climate Change and the Transition to a Low Carbon Economy: A Policy Briefing," New Economics Foundation.

Vayanos, D., and J.-L. Vila, 2009. "A Preferred-Habitat Model of the Term Structure of Interest Rates,” NBER Working Paper No. 15487.

Vermeulen, R., E. Schets, M. Lohuis, B. Kölbl, D.-J. Jansen, and W. Heeringa, 2018. "An energy transition risk stress test for the financial system of the Netherlands," Occasional Studies Volume 16-7, De Nederlandsche Bank.

Villeroy de Galhau, F., 2015. "Climate change: the financial sector and pathways to $2{ }^{\circ} \mathrm{C}$," Speech at COP21 Paris, Banque de France, November 30.

Vogt-Schilb, A., and S. Hallegatte, 2014. "Marginal abatement cost curves and the optimal timing of mitigation measures," Energy Policy 66:645-653.

Volz, U., 2017. "On the Role of Central Banks in Enhancing Green Finance," Inquiry Working Paper, United Nations Environment Programme. 
Weidmann, J., 2017. "Welcome and Opening Speech," OMFIF Global Public Investor Symposium on "Green bond issuance and other forms of low-carbon finance," July 13.

Weitzman, M. L., 1974. “Prices vs. Quantities," Review of Economic Studies 41(4):477-491.

Weitzman, M. L, 1998. "Why the far-distant future should be discounted at its lowest possible rate," Journal of Environmental Economics and Management 36(3):201-208.

Weitzman, M. L., 2009. "On Modeling and Interpreting the Economics of Catastrophic Climate Change," Review of Economics and Statistics 91(1):1-19.

Weitzman, M. L., 2010. "Risk-Adjusted Gamma Discounting," Journal of Environmental Economics and Management 60:1-13.

Weitzman, M. L., 2011. "Fat-Tailed Uncertainty in the Economics of Catastrophic Climate Change," Review of Environmental Economics and Policy 5(2):275-292.

World Bank, 2019a, "Finance Ministers Join Forces to Raise Climate Ambition," Press Release, World Bank Group, Washington, DC, April 13.

World Bank, 2019b. The Coalition of Finance Ministers for Climate Action: Helsinki Principles, World Bank Group, Washington, DC.

World Bank, 2019c. "Coalition of Finance Ministers for Climate Action: Explanatory Note to the Coalition Principles," World Bank Group, Washington, DC.

WWF, 2018. "A Warning Sign From our Planet: Nature Needs Life Support," 30 October 2018, World Wide Fund for Nature. Retrieved from:

https://www.wwf.org.uk/updates/living-planet-report-2018 